九州大学学術情報リポジトリ

Kyushu University Institutional Repository

\title{
CERAMBYCIDAE OF THE DANJO ISLANDS, WITH DESCRIPTIONS OF TWO NEW SPECIES AND SIX NEW SUBSPECIES (COLEOPTERA)"
}

Makihara, Hiroshi

https://doi.org/10.5109/2402

出版情報: ESAKIA. 15，pp.49-73，1980-10-31. Entomological Laboratory，Faculty of Agriculture， Kyushu University

バージョン：

権利関係 : 


\title{
CERAMBYCIDAE OF THE DANJO ISLANDS, WITH DESCRIPTIONS OF TWO NEW SPECIES AND SIX NEW SUBSPECIES (COLEOPTERA)*
}

\author{
Hiroshi MaKihara \\ Entomological Laboratory, Faculty of Agriculture \\ Kyushu University, Fukuoka 812, Japan
}

\begin{abstract}
The family Cerambycidae are represented on the Danjo Islands by nineteen species. Two new species and six new subspecies are endemic to this islands. New taxa described are Asaperda wadai and Rhodopina meshimensis, spp. nov., and Mesosa hirsuta brevihirsuta, Pterolophia caudata curtipennis, Palausybra tokaraensis depressa,Uraecha bimaculata brevicornis, Acalolepta nigricornis mogii and Acalolepta sejuncta morii, subspp. nov.
\end{abstract}

The Danjo Islands are composed of five islets, Oshima I., Kuroki I., Yorishima I., Hanagurijima I. and Meshima I. lying about $170 \mathrm{~km}$ southwest to Nagasaki.

The insular fauna treated in this paper is of great interest of its high percentage of endemicity. Of nineteen species of the family Cerambycidae known from the Danjo Islands, two speices and six subspecies described as new in this paper are known only from the Islands.

All the types of new species and subspecies are preserved in the collection of the Entomological Laboratory, Faculty of Agriculture, Kyushu University, Fukuoka.

I wish to express my sincere gratitude to Professor Y. Hirashima and Associate Professor K. Morimoto of Kyushu University for their continuous kind guidance. My thanks are due to Dr. Y. Wada of the National Institute of Health and Dr. M. Mogi of Saga Medical School, Mr. A. Mori of Nagasaki University, Mr. N. Ohbayashi of Kanagawa Horticultural Experiment Station, and Messrs. S. Imasaka and T. Takakuwa for the donation or the loan of the valuable specimens.

\footnotetext{
* Contribution from the Entomological Laboratory, Faculty of Agriculture, Kyushu University, Fukuoka (Ser. 3, No. 77).
} 


\section{Subfamily Cerambycinae}

Tribe CALLIDIOPINI

Ceresium fuscum Matsumura et Matsushita

(Fig. 2)

Ceresium fuscum Matsumura et Matsushita, 1932, Ins. Mats. $7(1 / 2): 67$.

Ceresium sinicum: Yamaguchi et al., 1973, nec White, Fauna and Flora Danjo Is. : 94.

Specimens examined: Meshima I. : 4 exs. 13. vi. 1978, A. Mori leg. ; 1 ex. 17. vi. 1978, A. Mori leg.; 2 exs. 29. vi. 1978, M. Mogi leg. ; 1 ex. 1. vii. 1978, M. Mogi leg.; 1 ex. 9. vii. 1978, Y. Wada leg. Oshima I. : 1 ex. 6. viii. 1972, M. Noda leg.

Distribution: Izu-Ôshima I., Miyake I., Mikura I., Hachijô I., Kanmurijima I., Okinoshima I. (Kôchi Pref.), Kyushu, Okinoshima I. (Fukuoka Pref.), Danjo I. (Oshima I. and Meshima I.), Koshiki Is., Tanegashima I., Yakushima I., Kuroshima I., Kuchinoerabu I., Nakanoshima I., Takara I., Kikai I., Ama-

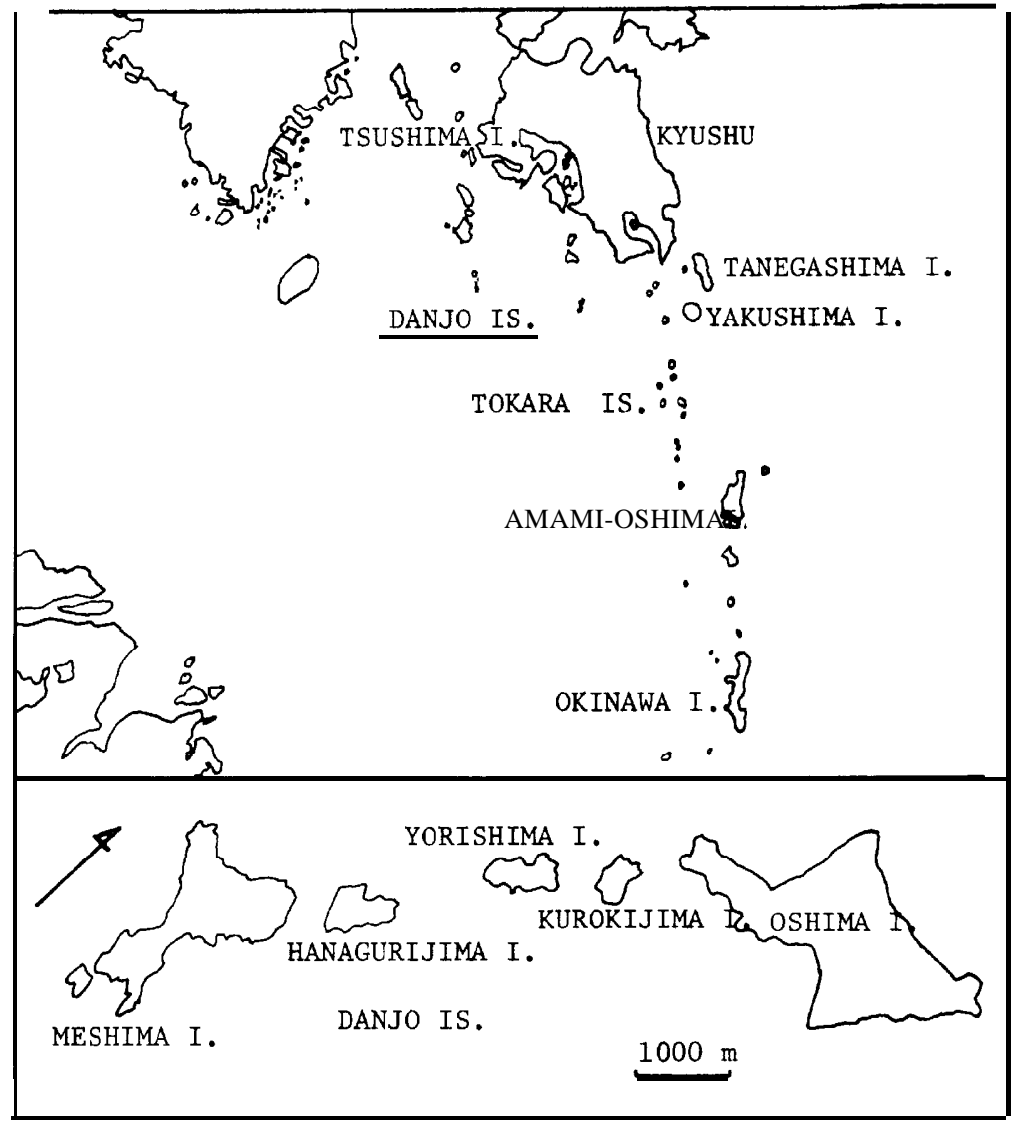

Fig. 1. A map of Danjo Islands. 
mi-Ôshima I., Kuchinoshima I., Tokunoshima I., Okinoerabu I., Okinawa I., Miyako I., Tarama I., Ishigaki I., Iriomote I., Hateruma I. and Yonaguni I.

\section{Ceresium simile Ga han}

(Fig. 3)

Ceresium simile Gahan, 1890, Ann. Mag. Nat. Hist. (6)5: 169; Yamaguchi et al., 1973, Fauna and Flora Danjo Is.: 94.

Specimens examined: Meshima I. : 1 ex. 9. vii. 1978, Y. Wada leg. : 2 exs. 13. vii. 1978 , Y. Wada leg. ; 1 ex. 19. vii. 1978, Y. Wada leg.

Distribution: Honshu, Izu-Ôshima I., Niijima I., Shikine I., Kôzu I., Miyake I., Mikura I., Hachijô I., Kanmurijima I., Shikoku, Kyushu, Bonin Is., Okinoshima I. (Fukuoka Pref.), Danjo Is. (Oshima I. and Meshima I.), Yakushima I., Kuroshima I., Kuchinoerabu I., Kuchinoshima I., Nakanoshima I., Takara I., Yokoate I., Amami-Ôshima I., Tokunoshima I., Okinawa I., Miyako I., Ishigaki I., and Iriomote I.

\section{Tribe ClYTiNI}

\section{Chlorophorus muscosus (Bat es)}

\section{(Fig. 4)}

Clytanthus muscosus Bates, 1873, Ann. Mag. Nat. Hist. (4)12: 198.

Chlorophorus muscosus: Matsushita, 1933, Jour. Fac. Hokkaido Imp. Univ. 34(2): 284.

Specimens examined: Meshima I. : 1 ex. 6. vi. 1978, A. Mori leg. ; 1 ex. 13. vi. 1978, A. Mori leg. ; 2 exs. 14. vi. 1978, A. Mori leg. ; 3 exs. 16. vi. 1978, A. Mori leg. ; 2 exs. 28. vi. 1978, M. Mogi leg. ; 5 exs. 29. vi. 1978, M. Mogi leg. ; 1 ex. 11. vii. 1978. Y. Wada leg.

Distribution : Honshu, Izu-Ôshima I., Niijima I., Kôzu I., Miyake I., Mikura I., Hachijô I., Sado I., Awashima I., Bonin Is., Shikoku, Kyushu, Oki-
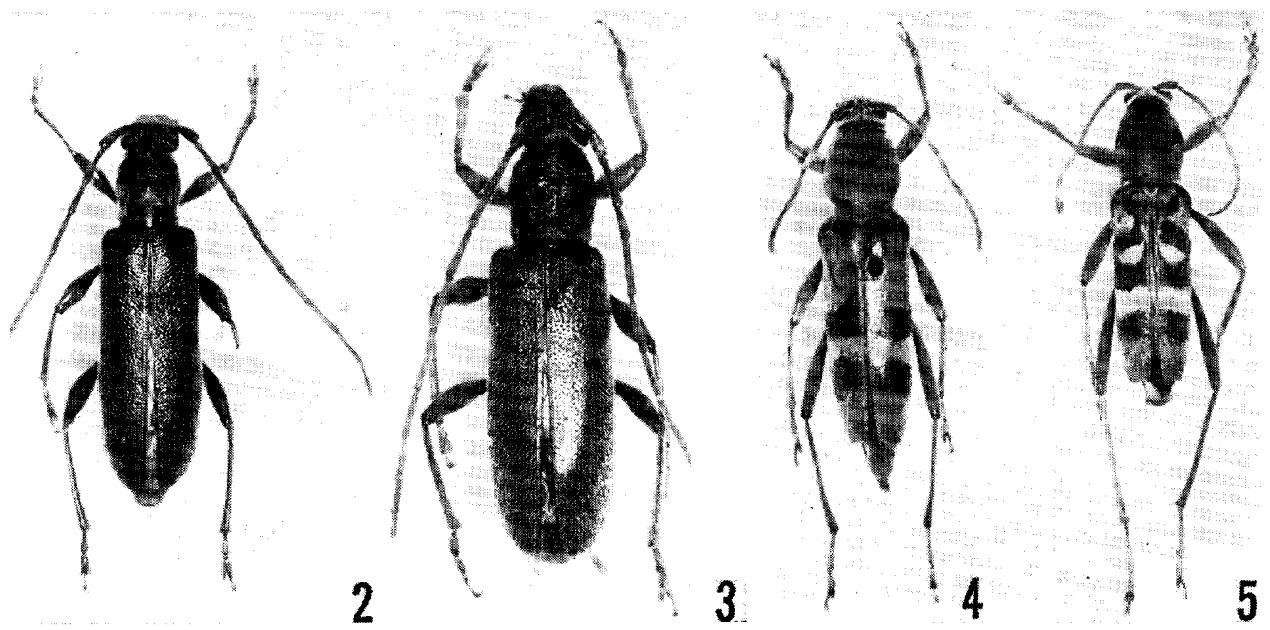

Figs. 2-5. Ceresium spp. and Chlorophorus spp. 2 : Ceresium fuscum. 3: Ceresium simile. 4: Chlorophorus muscosus. 5: Chlorophorus quinquefasciatus. 


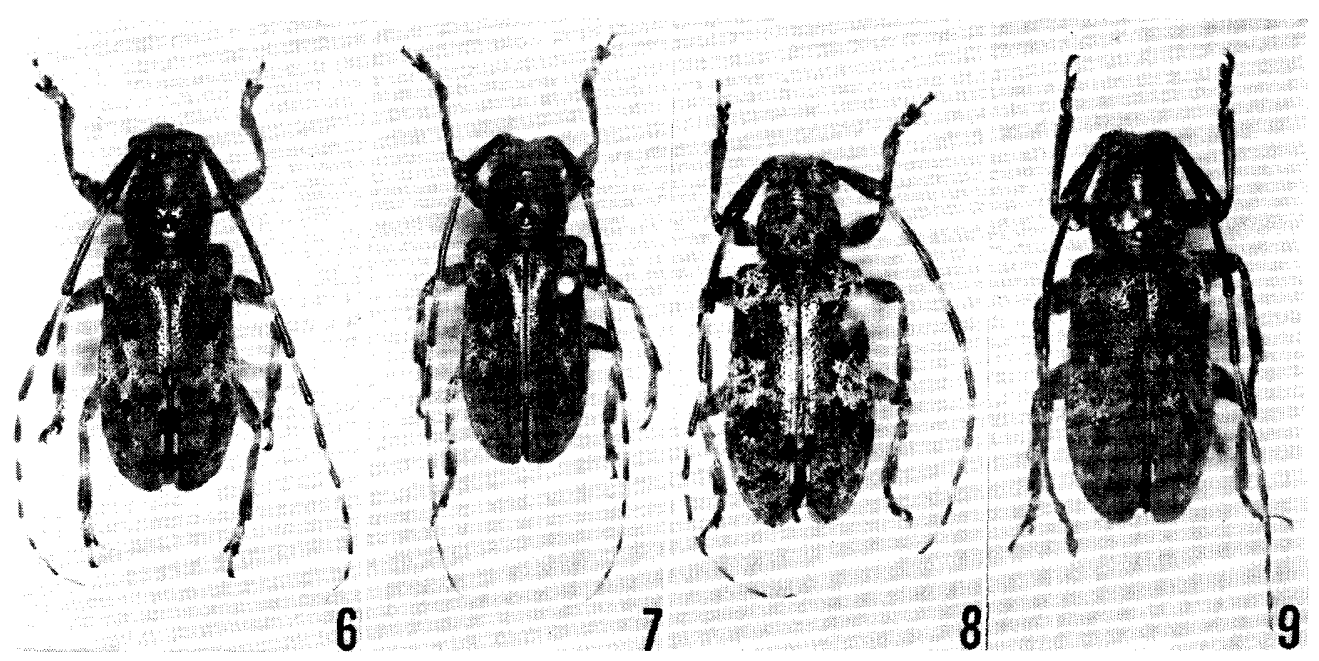

Figs. 6-9. Mesosa hirsuta subspp. 6: brevihirsuta from Meshima I. konishii from Tsushima I. 8: hirsuta from Kyushu. 9: continentalis from Korea. (males).

noshima I. (Fukuoka Pref.), Tsushima I., Danjo Is. (Meshima I.), Koshiki Is., Yakushima I., Kuroshima I., Tanegashima I., Kuchinoerabu I., Kuchinoshima I., Nakanoshima I., Takarajima I., Kikai I., Amami-Ôshima I., Tokunoshima I., Okinoerabu I. and Okinawa I.

Note: New record.

Chlorophorus quinquefasciatus (Castelnau et Gory)

(Fig. 5)

Clytus quinquefasciatus Castelnau et Gory, 1841, Hist. Nat. Icon. Ins. Col.: 101.

Chlorophorus quinquefasciatus : Kano, 1927, Trans. Nat. Hist. Soc. Formosa 17: 67; Yamaguchi et al., 1973, Fauna and Flora Danjo Is.: 94.

Specimens examined: Meshima I. : 1 ex. 30. vi. 1978, Mogi leg. ; 1 ex. 6. vii. 1978, M. Mogi leg. ; 1 ex. 11. vii. 1978, Y. Wada leg.

Distribution : Honshu, Awajishima I., Shikoku, Kyushu, Tsushima I., Okinoshima I. (Fukuoka Pref.), Koshiki Is., Danjo Is. (Oshima I. and Meshima I.), Yakushima I. Tanegashima I., Kuroshima I., Kuchinoerabu I., Kuchinoshima I., Nakanoshima I., Takara I., Kikai I., Amami-Ôshima I., Tokunoshima I., Okinoerabu I., Okinawa I., Kumejima I., Miyako I., Ishigaki I., Iriomote I. and Yonaguni I.: Korea and Quelpart I.

Chlorophorus yayeyamensis Kano

Chlorophorus yayeyamensis Kano, 1933, Kontyii 7: 137; Yamaguchi et al., 1973, Fauna and Flora Danjo Is.: 194.

Specimen examined: No example.

Distribution: Honshu (Yamaguchi Pref.), Hachijo I., Torishima I., Kyushu, Shikoku, Danjo Is. (Meshima I.), Tanegashima I., Yakushima I., Kuchino- 


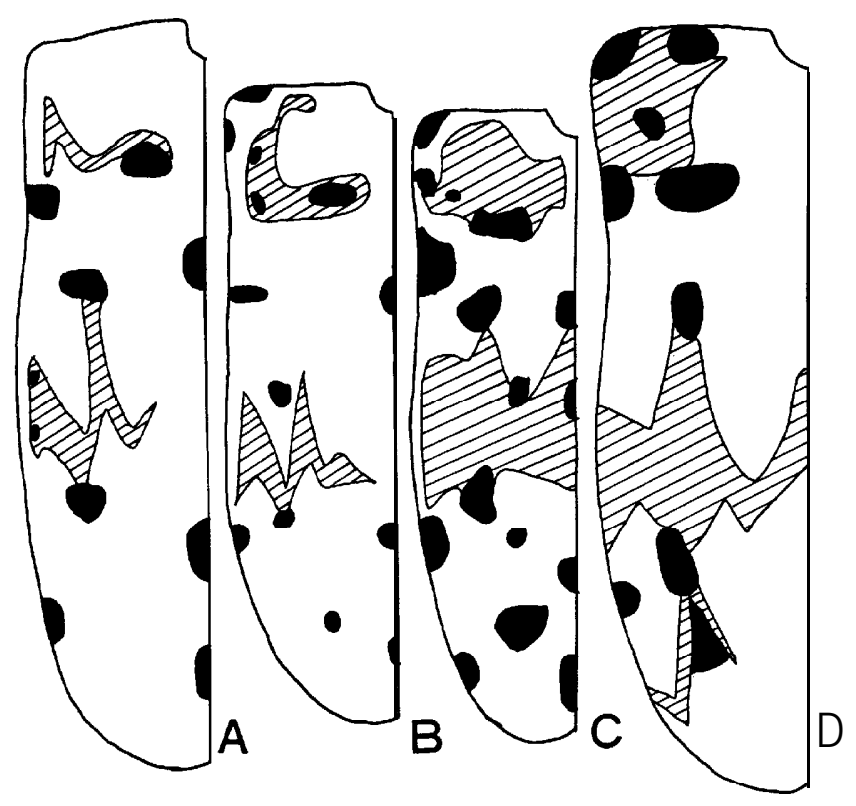

Fig. 10. Elytral markings of Mesosa hirsuta subspp. Parts of oblique lines denote white markings and black parts show black or brown markings. A: brevihirsuta. B: konishii. C: hirsuta. D : continentalis.

erabu I., Kuchinoshima I., Nakanoshima I., Suwanose I., Takara I., AmamiÔshima I., Tokunoshima I., Okinawa I., Miyako I., Ishigaki I., Iriomote I. and Hateruma I. ; Taiwan.

\author{
Subfamily LAMinaE \\ Tribe Mesosini \\ Mesosa hirsuta brevihirsuta subsp. nov. \\ (Figs. 6, $10 \mathrm{~A}$ and $11 \mathrm{~A}$ ) \\ This new subspecies is similar to $M$. hirsuta konishii Hayashi from Tsushi-
} ma I., but differs from it by the following points: Body covered with short brown pubescence ; elytral black pubescent markings larger; elytral white pubescent markings smaller on humeri; 7 th abdominal tergite shortened and concave roundly at apex in male.

Length : 13.3-15. $0 \mathrm{~mm}$ (male), $14.7 \mathrm{~mm}$ (female).

Distribution: Danjo Is. (Meshima I.).

Type Material: Holotype ð (Type No. 2199, Kyushu Univ.), Meshima I. of Danjo Is., 27. vi. 1978, M. Mogi leg. Paratypes : $2 \jmath^{\pi}$, same locality as holotype, 12. vii. 1978, Y. Wada leg.; 1 ○ 1 옹 same locality, 14. vii. 1978, Y. Wada leg. ; $1 \precsim$, same locality as above, 7 . vii. 1978, M. Mogi leg. 


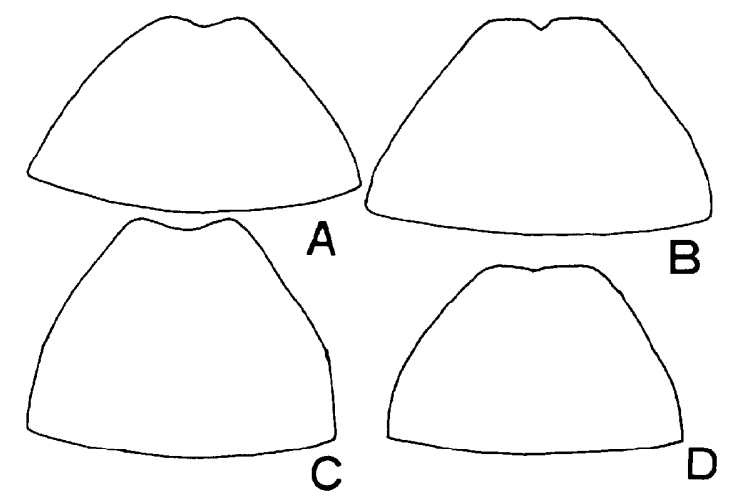

Fig. 11. Seventh abdominal tergite of Mesosa hirsuta subspp., dorsal view. A : brevihirsuta. B: konishii. C: hirsuta. D: continentalis. (males).

\section{K ey to subspecies of $M$. hirsuta Ba te S}

Body covered with long brown hairs.

Body covered with short brown hairs, elytral black pubescent markings somewhat larger, 7th abdominal tergite shortened and concave roundly at apex in male .................... M. hirsuta brevihirsuta subsp. nov. from Meshima I. of Danjo Is. Elytra with black pubescent markings

Elytra with brown pubescent markings, 7 th abdominal tergite slightly concave

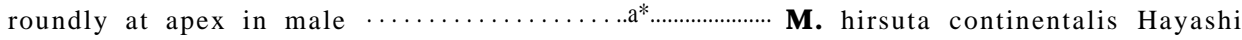
from Korea and E. Siberia (Figs. 9, $10 \mathrm{D}$ and $11 \mathrm{D})$ Elytra with small black and white pubescent markings; 7 th abdominal tergite truncate and slightly concave at apex in male ............... M. hirsuta konishii Hayashi from Tsushima I. (Figs. 7, $10 \mathrm{~B}$ and $11 \mathrm{~B}$ ) Elytra with large black and white pubescent markings; 7 th abdominal tergite long and concave widely and roundly at apex in male .......... M. hirsuta hirsuta Bates from Hokkaido, Honshu, Shikoku, Kyushu, Oki I., Awajishima I., Sado I., Kanmurijima I., Izu-Ôshima I., Niijima I., Shikinejima I., Miyake I., Koshiki Is., Tanegashima I. and Yakushima I. (Figs. 8, $10 \mathrm{C}$ and $11 \mathrm{C}$ )
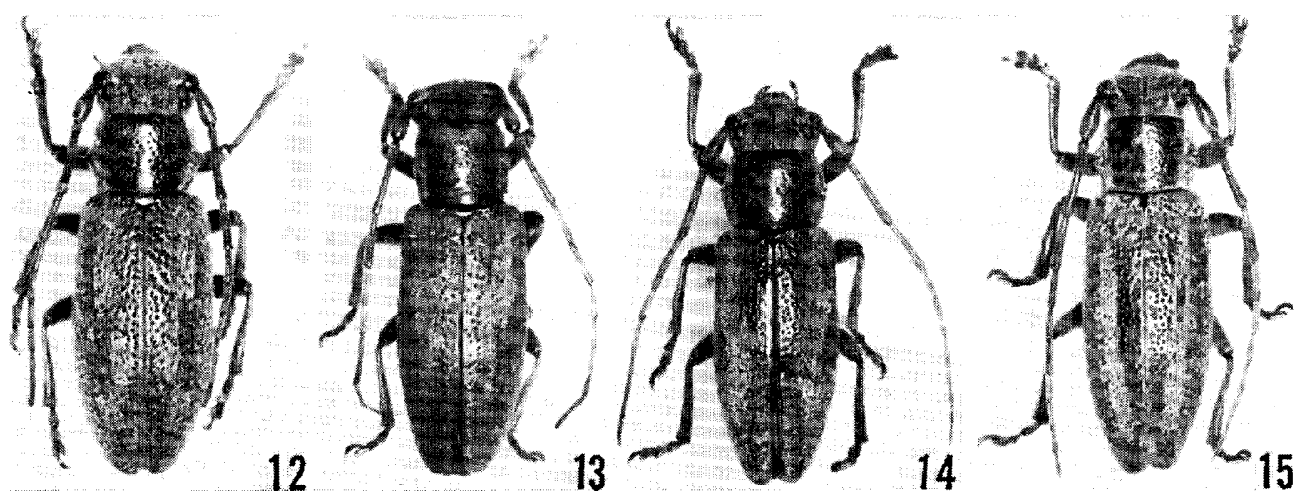

Figs. 12-15. Bumetopia spp. 12: japonica from Meshima I. 13: japonica from Tsushima I. 14: japonica from Kuroshima I. 15: oshimana from Amami-Ôshima I. 


\section{Tribe Homonoeini}

\section{Bumetopia japonica (Thomson)}

(Fig. 12)

Yochostyla japonica Thomson, 1868, Physis 2: 151.

Bumetopia japonica :Hayas hi, 1955, Col. illust. Ins. Japan 2: 174; Yamaguchi et al., 1973, Fauna and Flora Danjo Is. : 94.

Specimens examined : Meshima I. : 1 ex. 7, viii. 1972, M. Noda leg. ; 2 exs. 13. vi. 1978, A. Mori leg.; 1 ex. 17. vi. 1978, A. Mori leg. ; 2 exs. 25. vi. 1978, M. Mogi leg. ; 5 exs. 29. vi. 1978, M. Mogi leg. ; 1 ex. 18. vii. 1978, Y. Wada leg.

Distribution : Honshu (Yamaguchi Pref.), Kyushu, Tsushima I., Danjo I. (Meshima I.), Koshiki Is., Tanegashima I., Yakushima I., Takeshima I., Kuroshima I. and Kuchinoerabu I.

Note: Female of this species from Meshima I. is provided with the antennae very short.

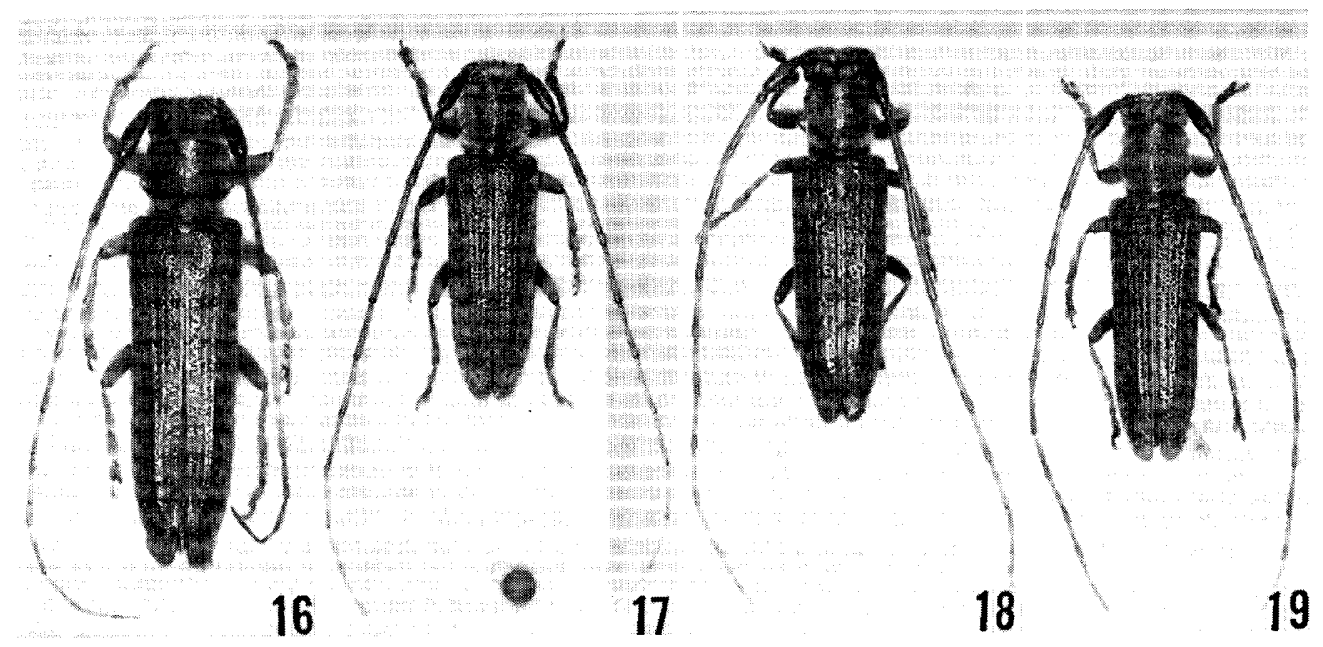

Figs. 16-19. Asaperda spp. 16: wadai from Meshima I. 17: bicostata from Nakanoshima I. 18: bicostata from Okinoerabu I. 19: bicostata from Okinawa I. (males).

\section{Tribe Apomecynini}

\section{Asaperda wadai sp. nov.}

(Figs. 16, $20 \mathrm{~A}$ and $21 \mathrm{~A}$ )

Male : Body black; antennae except for brown 11 th segment, femora, tibiae and apices of claws bright reddish brown; mouth parts and tarsi except for apices of claws blackish brown.

Head somewhat roughly punctured, covered with dense, rather long prostrate golden pubescence and sparse, long suberect white hairs; relative length of inferior eye lobes to gena 0.86; antennae short, relative length to 
body 1.30 , relative length of each segments $9.0: 1.4: 11.7: 11.3: 10.8: 10.4:$ $9.9: 8.6: 8.1: 10.4$; with oblique and prostrate brown pubescence except for basal parts of segments 4-10, where the pubescence yellow, ventral sides of segments 1-7 with coarse, long, oblique brown hairs, ventral side of segment 8 with two long oblique brown hairs, one on apical part and the other on basal part, ventral side of segment 9 with a long oblique brown hair on apical part.

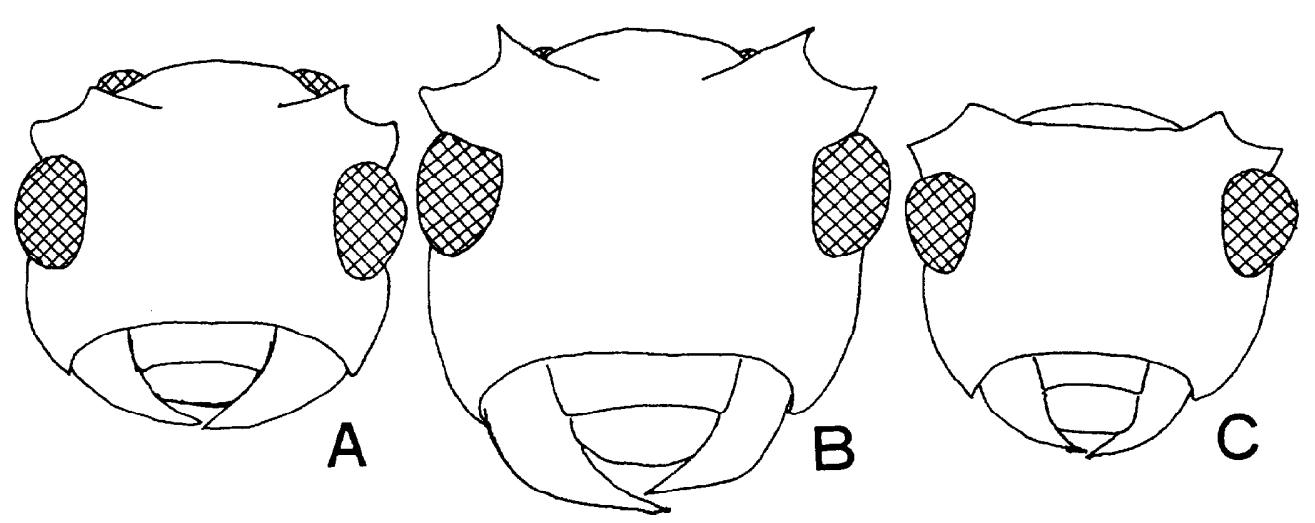

Fig. 20. Faces of Asaperda spp. A: wadai. B: bicostata from Nakanoshima I. C: bicostata from Okinoerabu I.

Pronotum as long as broad, with a weak projection at each side, closely with shallow punctures, densely covered with depressed golden pubescence and sparsely with erect long brown hairs.

Scutellum semicircular, the ratio of width to length $5: 4$, densely covered with similar hairs on head and pronotum.

Elytra slender, three times as long as broad, 2.8 times as long as head and pronotum combined ; humeri weakly developed ; disk deeply and somewhat coarsely punctured at basal half and shallowly at apical half, densely covered with prostrate short golden pubescence; apical parts rounded.

Ventral side closely punctured, densely clothed with prostrate golden yellow pubescence and sparsely with suberect long whitish yellow hairs.

Legs stout; femora rather closely with prostrate whitish yellow pubescence, the pubescence of fore femora erect or suberect and longer except for the ventral bases, where the pubescence inclined; tibiae with depressed and oblique rather long pubescence and sparsely with suberect long hairs of the same colour as femora, inclined golden setae provided on ventral apices of tibiae, apices and apical $1 / 3$ of mid and hind tibiae at dorsal parts; tarsi densely with depressed yellow pubescence on dorsal sides and oblique golden pubescence on ventral sides, and sparsely with suberect long brown setae on dorsal sides, 


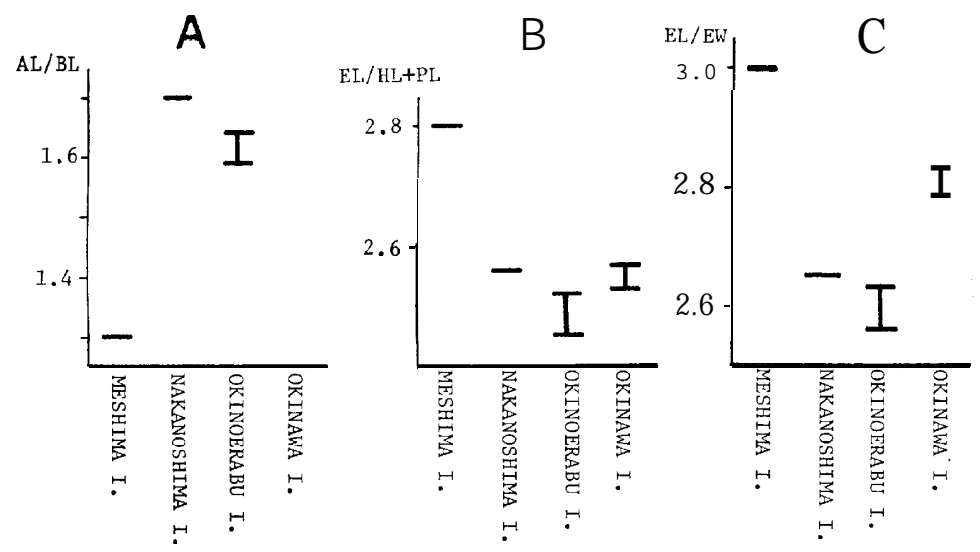

Fig. 21. Asaperda spp. A: Relative length of antenna to body. B: Relative length of elytra to head and pronotum combined. C: Relative length of elytral length to width.

Length: $8.6 \mathrm{~mm}$.

Distribution: Danjo Is. (Meshima I.).

Type material: Holotype $\overbrace{}^{(T y p e ~ N o . ~ 2200, ~ K y u s h u ~ U n i v .), ~ M e s h i m a ~ I . ~}$ of Danjo Is., 14. v. 1978, Y. Wada leg.

Diagnosis: This new species is related to A. bicostata Hayashi from Yakushima I., Kuroshima I., Kuchinoerabu I., Kuchinoshima I., Nakanoshima I., Amami-Ôshima I., Tokunoshima I., Okinoerabu I. and Okinawa I., but separable from it by the following points.

A. wadai sp. nov.

Body slender ; head, pronotum and elytra black and covered with golden pubescence ; relative length of inferior eye lobes to gena 0.86 ; antennae shorter, relative length to body 1.30; elytra long, relative length to width 3.00 and relative length to head and pronotum combined 2.80; antennae and legs except for tarsi bright reddish brown, and tarsi blackish brown; pronotum and elytra weakly punctured.

A. bicostata Hayas hi

Body rather stout; head and pronotum blackish brown, elytra, antennae and legs dark reddish brown; head and pronotum covered with light golden yellow pubescence, elytra with greyish yellow and grey pubescence; relative length of inferior eye lobes to gena 1.14-1. 33; antennae longer, relative length to body 1.52-1.80; elytra rather short, relative length to width 2.56-2.84, relative length to head and pronotum combined 2.45-2.57; pronotum and elytra strongly punctured. 


\section{Sybra baculina nipponensis Hayashi}

(Fig. 67)

Sybra posticalis baculina; Hayashi, 1956, Bull. Osaka Mun. Mus. Nat. Hist. 9: 11, 22.

Sybra baculina: Ohbayashi, 1963, Icon. Ins. Japon. col. nat. edita 2: 311; Yamaguchi et al., 1973, Fauna and Flora Danjo Is.: 94.

Sybra baculina nipponensis Hayashi, 1972, Ent. Rev. Japan $24(1 / 2): 32$.

Specimens examined: Meshima I. : 1 ex. 25. vi. 1978, M. Mogi leg. ; 14 exs. 29. vi. 1978, M. Mogi leg.; 4 exs. 7. vii. 1978, M. Mogi leg. ; 1 ex. 13. vii. 1978, Y. Wada leg. ; 4 exs. 18. vii. 1978, Y. Wada leg.

Distribution: Shikoku, Kyushu, Okinoshima I. (Kôchi Pref.), Danjo Is. (Oshima I. and Meshima I.), Koshiki Is., Tanegashima I., Yakushima I., Kuroshima I., Kuchinoerabu I., Kuchinoshima I., Nakanoshima I. and Takara I.

\section{Palausybra tokaraensis depressa subsp. nov.}

(Figs. 22 and $25 \mathrm{~A}$ )

This new subspecies is related to $P$. tokaraensis tokaraensis Makihara from Kuroshima I. and Nakanoshima I. of Kagoshima Pref., but differs from it by the following points.

$P$. tokaraensis depressa subsp. nov.

Antennal segments 5-11 with grey pubescence at base; pronotum and elytra with robust whitish yellow pubescence; elytra rather flattened at basal half; red part of elytral disk small ; legs with robust silvery white setae.

P. tokaraensis tokaraensis Maki hara

Antennal segments 5-11 without grey pubescence at base; pronotum and elytra with not robust golden yellow pubescence ; elytra inflated at basal half; part of elytral disk large; legs with slender golden setae.
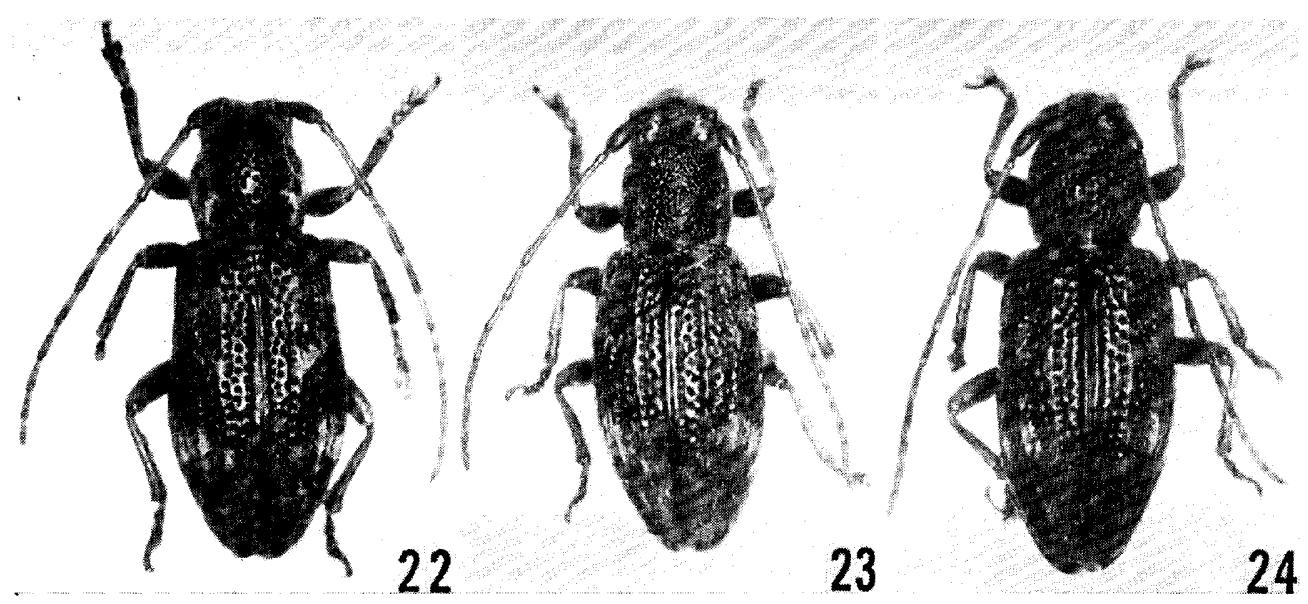

Figs. 22-24. Palausybra tokaraensis subspp. 22: depressa from Meshima I. 23: tokaraensis from Kuroshima I. 24: tokaraensis from Nakanoshima I. (females). 


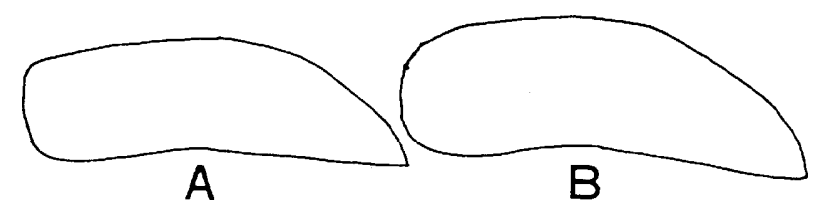

Fig. 25. Lateral view of elytra, Palausybra tokaraensis subspp. A: depressa. B: tokaraensis.

Length : $6.9 \mathrm{~mm}$.

Distribution: Danjo Is. (Meshima I.),

Type material: Holotype 우 (Type No. 2201, Kyushu Univ.), Meshima I. of Danjo Is., 29. vi. 1978, M. Mogi leg.

Correction: The single paratype, female of P. tokaraensis tokaraensis Makihara from Nakanoshima I., was mistaken as male in my previous paper, "Cerambycidae of Kuroshima Island", Esakia 10: 54, 1977.

\section{Tribe Pteroplinn}

Pterolophia caudata curtipennis subsp. nov.

(Fig. 26)

This new subspecies is related to $P$. caudata caudata (Bates) from Hokkaido, Honshu, Shikoku, Kyushu, Sado I., Awajishima I., Kanmurijima I., IzuÔshima I., Niijima I., Miyake I., Tsushima I., Koshiki Is. and Tanegashima I., but differs from it by the following points.

$P$. caudata curtipennis subsp. nov.

Antennae densely covered with yellowish brown pubescence; elytra short, relative length to width 2.00 and relative length to head and pronotum combined 2.09.

P. caudata caudata (Bates) (Fig. 27)

Antennae spottedly covered with grey pubescence; elytra long, relative length to width 2.10-2.20 and relative length to head and pronotum combined 2.15-2.45.

Length : $13.3 \mathrm{~mm}$.

Distribution: Danjo Is. (Meshima I.)

Type material: Holotype $\sigma($ Type No. 2202, Kyushu Univ.), Meshima I. of Danjo Is., 18. vii, 1978, Y. Wada leg.

\section{Pterolophia annulata (Chevrolat)}

(Fig. 28)

Specimens examined: Meshima I. : 2 exs. 13. vi. 1978, A. Mori leg. ; 1 ex. 26. vi. 1978, M. Mogi leg.; 4 exs. 29. vi. 1978, M. Mogi leg. ; 1 ex. 6. vii. 1978, M. Mogi leg. ; 1 ex. 7. vii. 1978, M. Mogi leg. ; 2 exs. 9. vii. 1978, Y. Wada leg. ; 2 exs. 10. vii. 1978, Y. Wada leg.; 2 exs. 13. vii. 1978, Y. Wada leg. ; 1 ex. 16. vii. 1978, Y. Wada leg. 


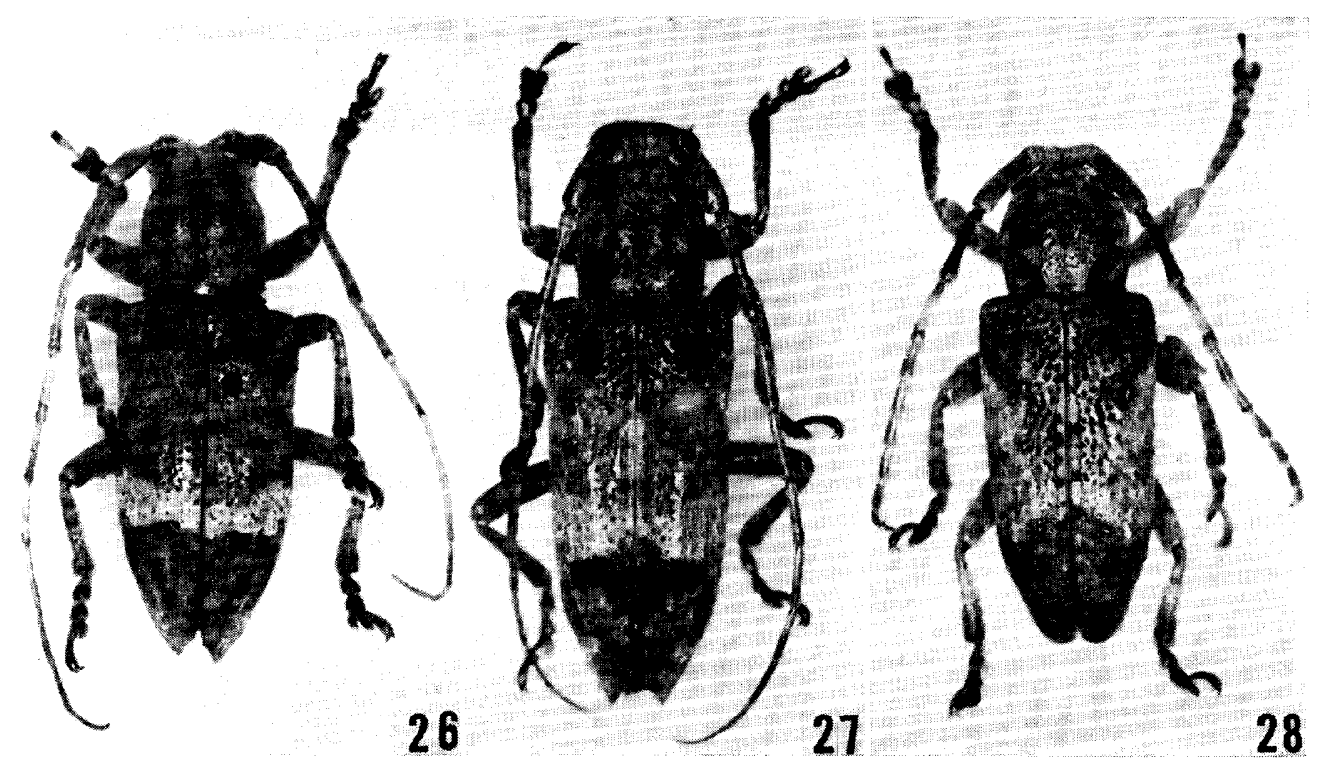

Figs. 26-28. Pterolophia spp. 26: caudata curtipennis from Meshima I. 27: caudata from Kyushu. 28: annulata from Meshima I. 26 and 27: males, and 28: female.

Distribution : Honshu, Shikoku, Kyushu, Sado I., Oki I., Awajishima I., Izu-Ôshima I., Niijima I., Kôzu I., Miyake I., Hachijo I., Tsushima I., Danjo Is. (Meshima I.), Koshiki I., Tanegashima I., Yakushima I., Kuroshima I., Kuchinoerabu I., Kuchinoshima I., Nakanoshima I., Takara I., Kikai I., Amami-Ôshima I., Tokunoshima I., Okinoerabu I., Okinawa I., Miyako I., Tarama I., Ishigaki I., Iriomote I., Hateruma I., Irabu I. and Yonaguni I.; Korea, Taiwan, China, Hainan I., Hong-Kong, Macao and Burma.

\section{Tribe Agnisn}

\section{Uraecha bimaculata brevicornis subsp. nov.}

(Figs. 29, 33, $37 \mathrm{~A}$ and 38A)

This new subspecies is related to U.bimaculatabimaculata Thomson from Hokkaido, Honshu, Shikoku, Kyushu, Oki I., Awajishima I., Kanmurijima I., IzuOshima I., Niijima I., Miyake I., Tanegashima I., Yakushima I. and Tsushima I., but differs from it by the following points: Antennae very short, 2.27 (male) or 1.72 (female) times as long as body; elytral apices sharply hooked.

\section{KEY TO SUBSPECIES OF $U$.bimaculata OF KYUSHU AND NEIGHBOURING ISLANDS}

1. Antennae longer, more than 2.5 (male) or 1.8 (female) times as long as body, elytral apices not hooked (Fig. 37 B, C. D)

- Antennae shorter, less than 2.3 (male) or 1.8 (female) times as long as body, elytral apices sharply hooked (Fig. 37A) …....... U. bimaculata brevicornis subsp. nov. from Meshima I, and Oshima I, of Danjo Is. 
2. Elytral apices not so strongly sharpened (Fig. $37 \mathrm{C}, \mathrm{D}$ )

- Elytral apices strongly sharpened (Fig. 37B)

U. b. bimaculata Thomson from Tsushima I. (Figs. 30 and 34)
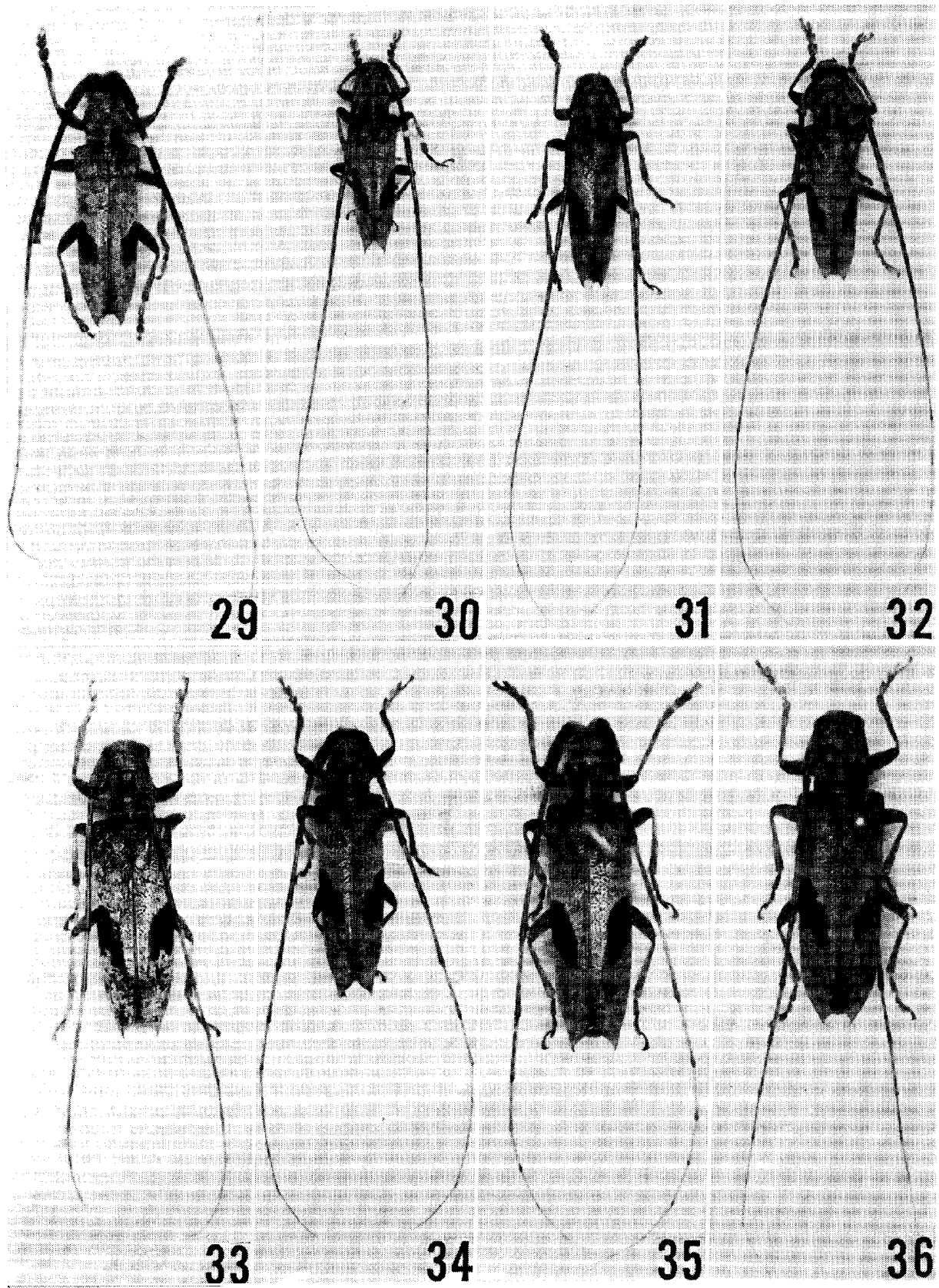

Figs. 29-36. Uraecha bimaculata subspp. 29-32 : males and 33-36: females. 29 and 33 : brevicornis from Danjo Is. 30 and 34: bimaculata from Tsushima I. 31 and 35: bimaculata from Kyushu. 32 and 36: bimaculata from Yakushima I. 
3. Elytral apices somewhat strongly sharpened (Fig. 37 C) …. U. b. bimaculata Thomson from Kyushu excluding South Kyushu (Figs. 31 and 35)

- Elytral apices weakly sharpened (Fig. 37D) U. b. bimaculata Thomson from South Kyushu, Tanegashima I. and Yakushima I. (Figs. 32 and 36)

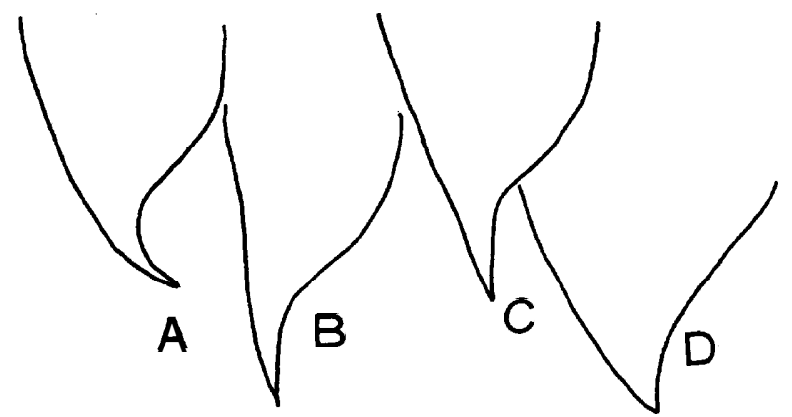

Fig. 37. Elytral apices of Uraecha bimaculata subspp. A : brevicornis from Meshima I. B: $b i$ maculata from Tsushima I. C: bimaculata from Kyushu. D: bimaculata from Yakushima I.

Length : $19.8 \mathrm{~mm}$ (male), $23.3 \mathrm{~mm}$ (female).

Distribution: Danjo Is. (Oshima I. and Meshima I.).

Type material: Holotype $\precsim$ (Type No. 2203, Kyushu Univ.), Meshima I. of Danjo Is., 21 vi. 1978, A. Mori leg. Paratype :ㅇ, Oshima I. of Danjo Is., 7. viii. 1972, M. Noda leg,

\section{Acalolepta nigricornis mogii subsp.nov.}

(Fig. 39)

This new subspecies is separated from A. nigricornis nigricornis Makihara by the characters given in the following key in female. Because A. nigricornis is a close relative of $\mathbf{A}$. fraudatorix, the distinguishing characters of them (females) of neighbouring islands are also given below.

1. Body covered with brown pubescence

- Body covered with dark greyish brown pubescence

2. Antennae long, relative length to body 1.62 -L 63 ; relative length of each antennal segment $9.0: 0.9: 14.6: 11.6: 9.8: 8.7: \mathbf{8 . 7}: \mathbf{8 . 2}: \mathbf{8 . 2}: \mathbf{8 . 3}: \mathbf{1 2}$. 1 ; elytra rather long, about 2.3 times as long as wide and 2.7 times as long as head and pronotum combined

A. fraudatorix yakushimana Yokoyama from Tanegashima I. and Yakushima I. (Fig. 42)

- Antennae short, relative length to body $1.38-1.42$; relative length of each antennal segment $9.9: 0.9: 15.6: 11.3: 9.9: 8.6: 8.8: 8.5: 7.9: 7.9:$ 10.6; elytra rather short, about 2.2 times as long as wide and 2.5 times as long as head and pronotum combined …........... A. fraudatorix satoi Breuning et Ohbayashi from Tsushima I. (Fig. 41)

3. Body black; antennae rather short, relative length to body 1.56-1. 60; relative length of each antennal segment $1.0: 0.6: 14.3: 10.8: 9.6: 8.6: 8.9: 8.3: 8.1$ : 8. $0: 12$. 7; elytra rather short, relative length to width 2. 05-2. 16

A. nigricornis mogii subsp. nov. from Meshima I. of Danjo Is. 
- Body blackish brown; antennae long, relative length to body 1.73-1. 81; relative length of each antennal segment $8.7: 0.7: 14.3: 11.0: 9.7: 8.8: 8.8: 8.5: 8.4:$

8.3 : 12.9; elytra rather long, relative length to width $2.21-2.31$

A. nigricornis nigricornis Maki $h$ ara from Kuroshima I. of Kagoshima Pref. (Fig. 40)

Length : 20.1-24.7 mm (female).

Distribution: Danjo Is. (Meshima I.).

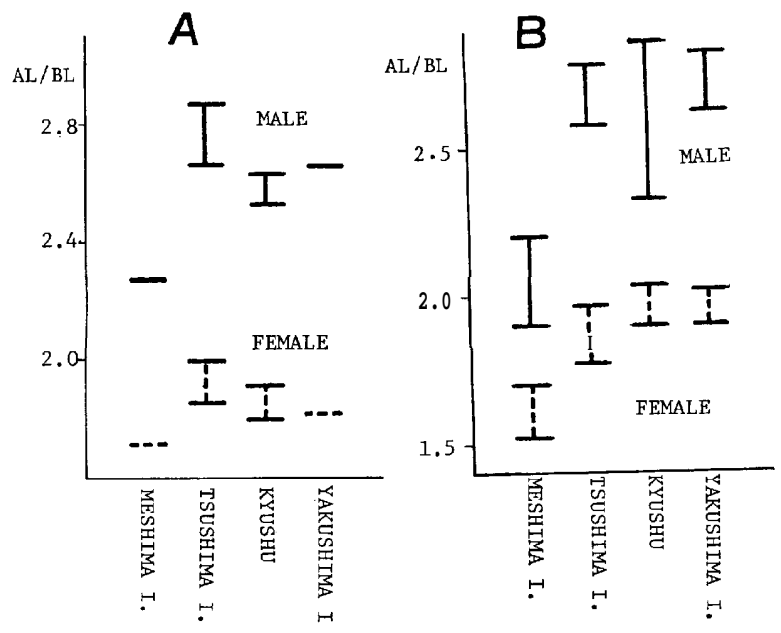

Fig. 38. Relative length of antenna to body. A: Uraechabimaculata subspp. B: Acalolepta sejuncta subsp.
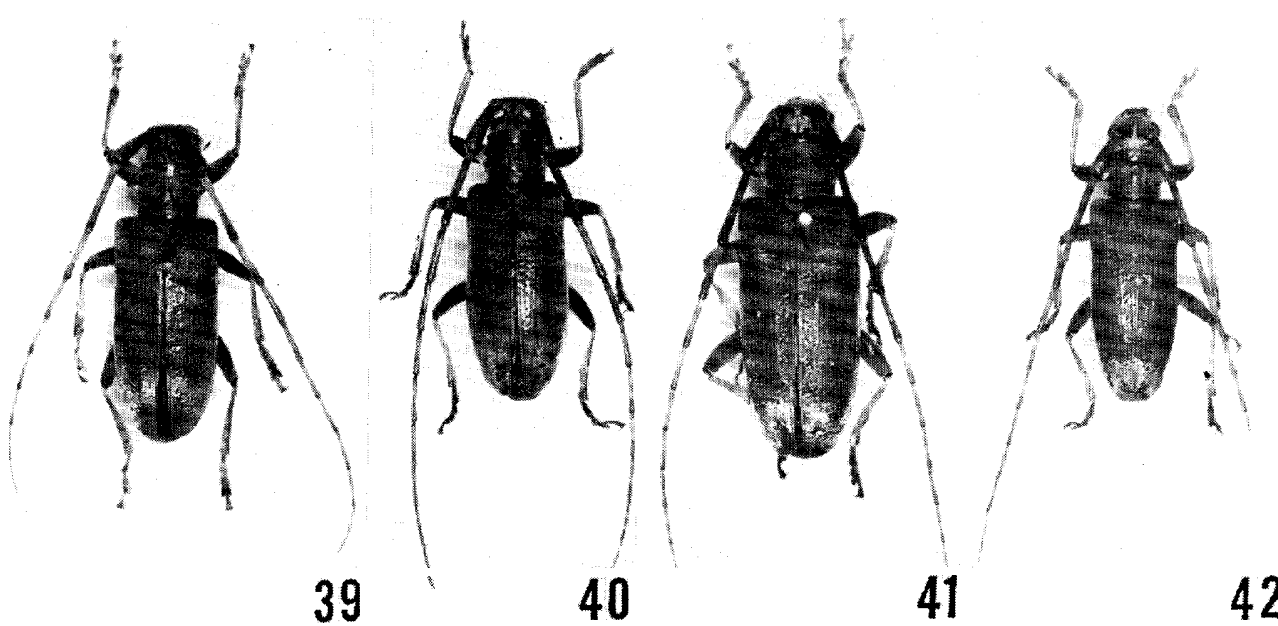

Figs. 39-42. Acalolepta spp. 39 : nigricornis mogii from Meshima I. 40 : nigricornis nigricornis from Kuroshima I. 41: fraudatorix satoi from Tsushima I. 42: fraudatorix yakushimana from Yakushima I. (females). 
Type materiad: Holotype 우 (Type No. 2204, Kyushu Univ.), Meshima 1. of Danjo Is., 6. vii. 1978, M. Mogi leg. Paratypes : 우, same locality and collector as holotype, 25. vi. 1978; 우, same locality as holotype, 18. vii, 1978, Y. Wada leg.

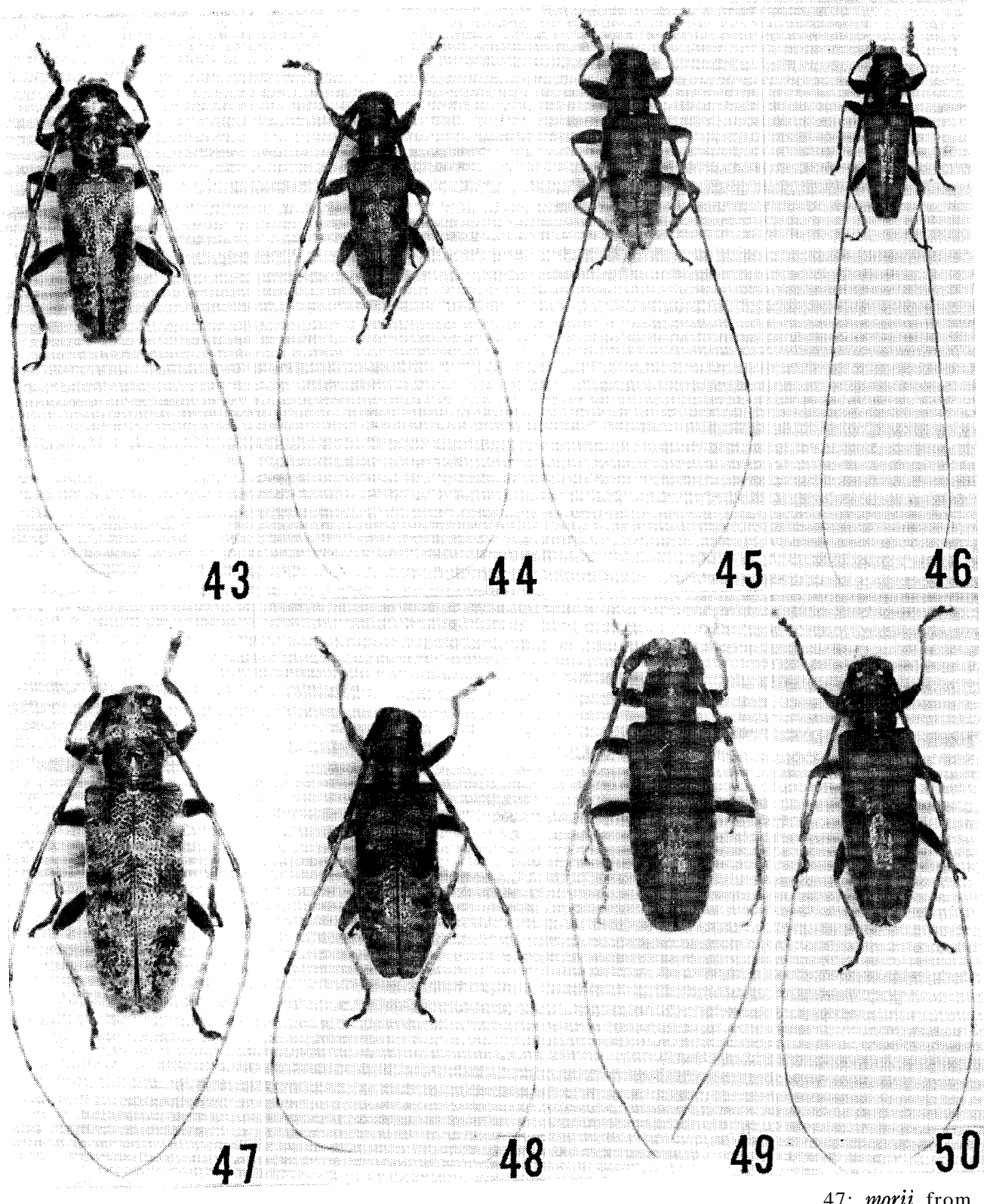

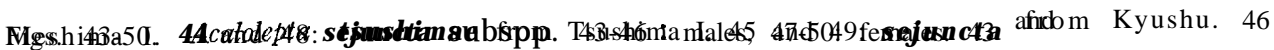
and 50: sejuncta from Yakushima I. 


\section{Acalolepta sejuncta morii subsp. nov.}

(Figs. 43, 47, $38 \mathrm{~B}$ and $51 \mathrm{~A}$ and $\mathrm{E}$ )

This new subspecies is related to A. sejuncta tsushinzae Breuning from Tsushima I. and A. sejuncta sejuncta (Bates) from Hokkaido to Kyushu, but differs from them by the following points:

A. sejuncta morii subsp. nov.

Antennae short, relative length to body 1.90-2.20 (male) or 1.52-1.70 (female) ; body covered with silver grey pubescence ; 7th abdominal tergite weakly concave at apex in male (Fig. $51 \mathrm{~A}$ ) ; parameres of male genitalia hardly concave internally at middle (Fig. $51 \mathrm{E}$ ).

A. sejuncta tsushimae Breuning and A. sejuncta sejuncta (Bates) of Kyushu and Yakushima I. (Figs. 44-46, 48-50 and 51 B-D, F-H)

Antennae long, relative length to body 2.42-2.84 (male) or 1.68-2.02 (female) ; body covered with brown pubescence; 7th abdominal tergite strongly concave at apex in male (Figs. $51 \mathrm{~B}, \mathrm{C}, \mathrm{D})$; parameres of male genitalia rather concave internally at middle (Figs. $51 \mathrm{~F}, \mathrm{G}, \mathrm{H}$ ).

Length : 12.9-19.0 mm (male), 14.6-19.0 mm (female).

Distribution: Danjo Is. (Oshima I. and Meshima I.).

Type material: Holotype ð (Type No. 2205, Kyushu Univ.), Meshima I.

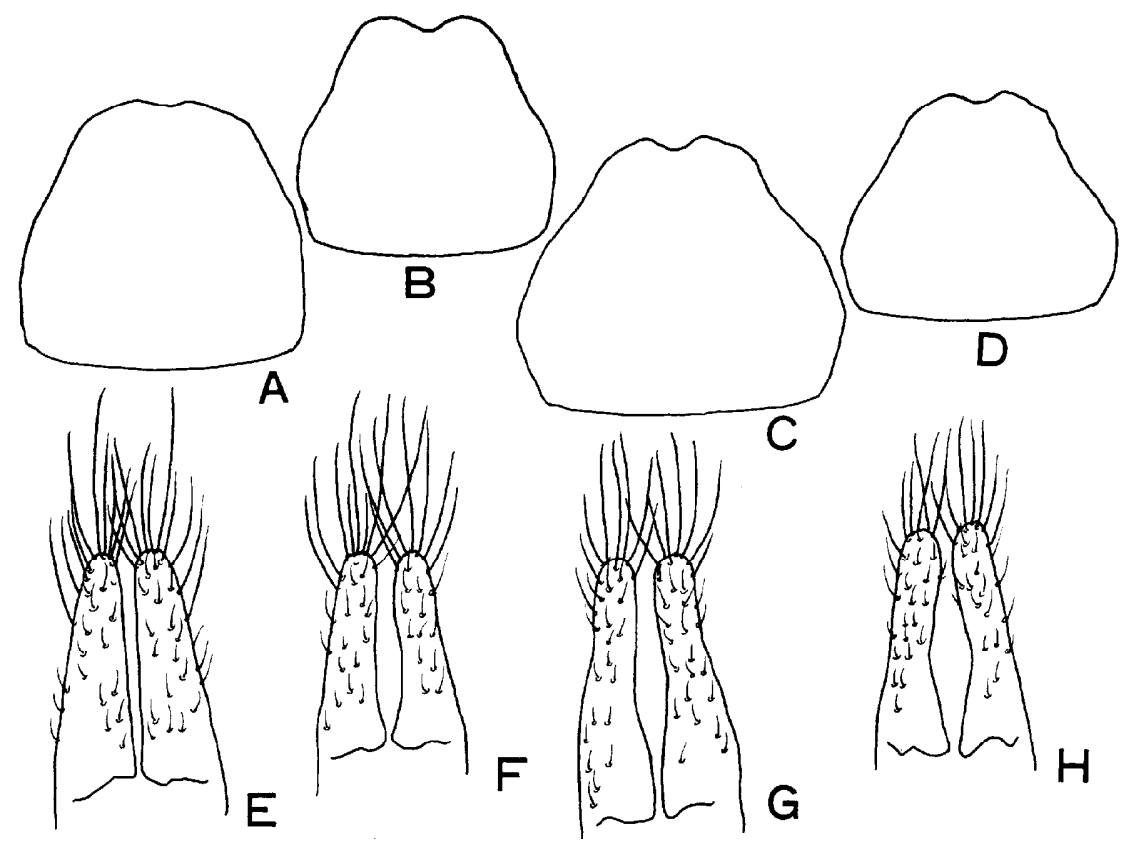

Figs. 51. Acalolepta sejuncta subspp. A-D: 7th abdominal tergite of male. E-H: Parameres of male genitalia. A and E: morii from Meshima I. I3 and F: tsushimae from Tsushirna I. $\mathrm{C}$ and G: sejuncta from Kyushu. D. and H: sejuncta from Yakushima I. 

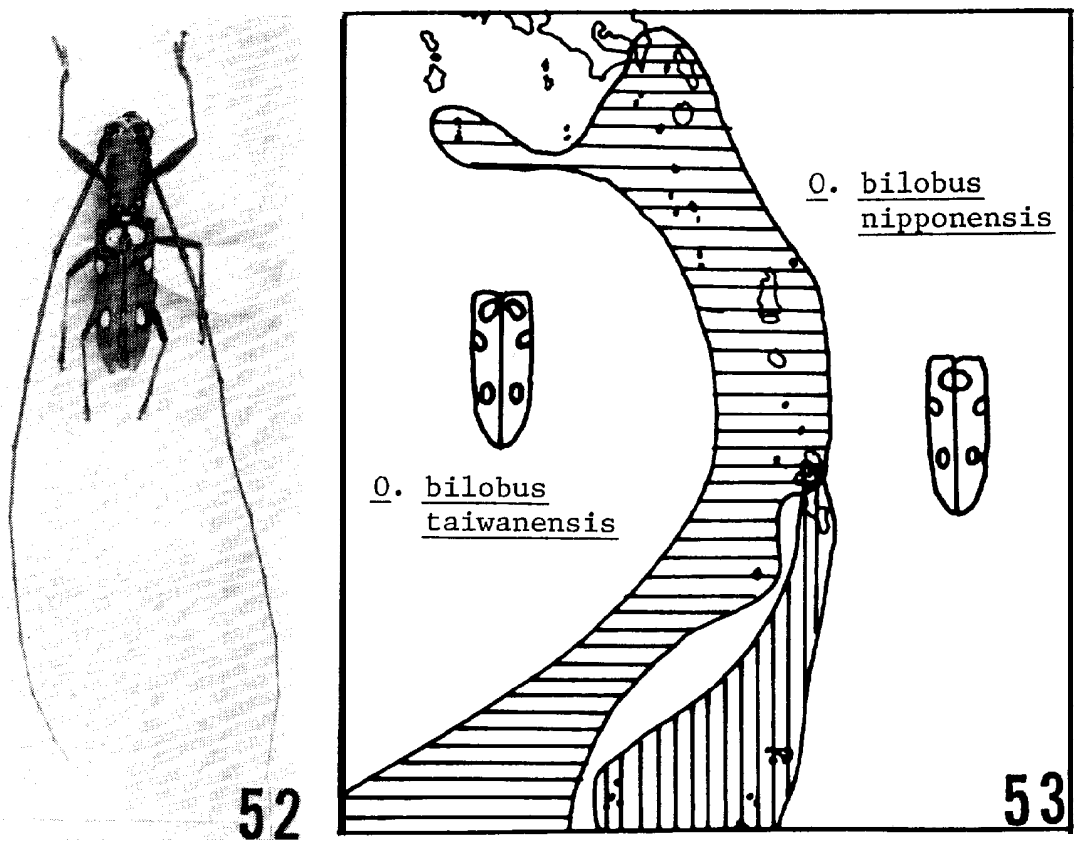

Figs. 52 and 53. Olenecamptus bilobus taiwanensis. 52 : O. bilobus taiwanensis from Meshima I. 53 : Distribution map.

of Danjo Is., 20. vi. 1978, A. Mori leg. Paratypes: Љ, same locality as holotype, 2. viii. 1972, M. Noda leg.; $1 \precsim 2$ 우우 same locality as holotype, 29. vi, 1978, M. Mogi leg. ; 우, same locality as holotype, 12. vii. 1978, Y. Wada leg. ; ð, same locality as above, 18. vii. 1978, Y. Wada leg. ; 우, Oshima I., 6. viii. 1972, M. Noda leg.

Tribe Dorcaschematini

Olenecamptus bilobus taiwanensis Dillon et Dillon

(Figs. 52 and 53)

Olenecamptusbilobus taiwanensis Dillon et Dillon, 1948, Trans. Amer. Ent. Soc. 73: 229.

Specimens examined: Meshima I.: 6 exs. 6. vii. 1978, M. Mogi leg. ; 1 ex. 12. vii. 1978, Y. Wada leg.; 1 ex. 15 . vii. 1978, Y. Wada leg.

Distribution : Danjo Is. (Meshima I.), South Kyushu, Yakushima I., Takeshima I., Kuchinoshima I., Nakanoshima I., Suwanose I., Takara I., Amami-Ôshima I., Kikai I., Tokunoshima I., Okinoerabu I., Kumejima I. and Northern part of Okinawa I.; Taiwan.

Tribe RHODOPININI

\section{Rhodopina meshimensis sp. nov.}

(Figs. 54, $64 \mathrm{~A}, 65 \mathrm{~A}$ and $66 \mathrm{~A}, \mathrm{~L}$ )

Female: Body blackish brown; antenna1 segments 3-6 and claws reddish 
brown.

Head roughly punctured except for gena and antenna1 supports, covered with prostrate sulphureous yellow pubescence and with suberect long golden yellow hairs on gena, vertex and frons at lateral and apical sides; inferior
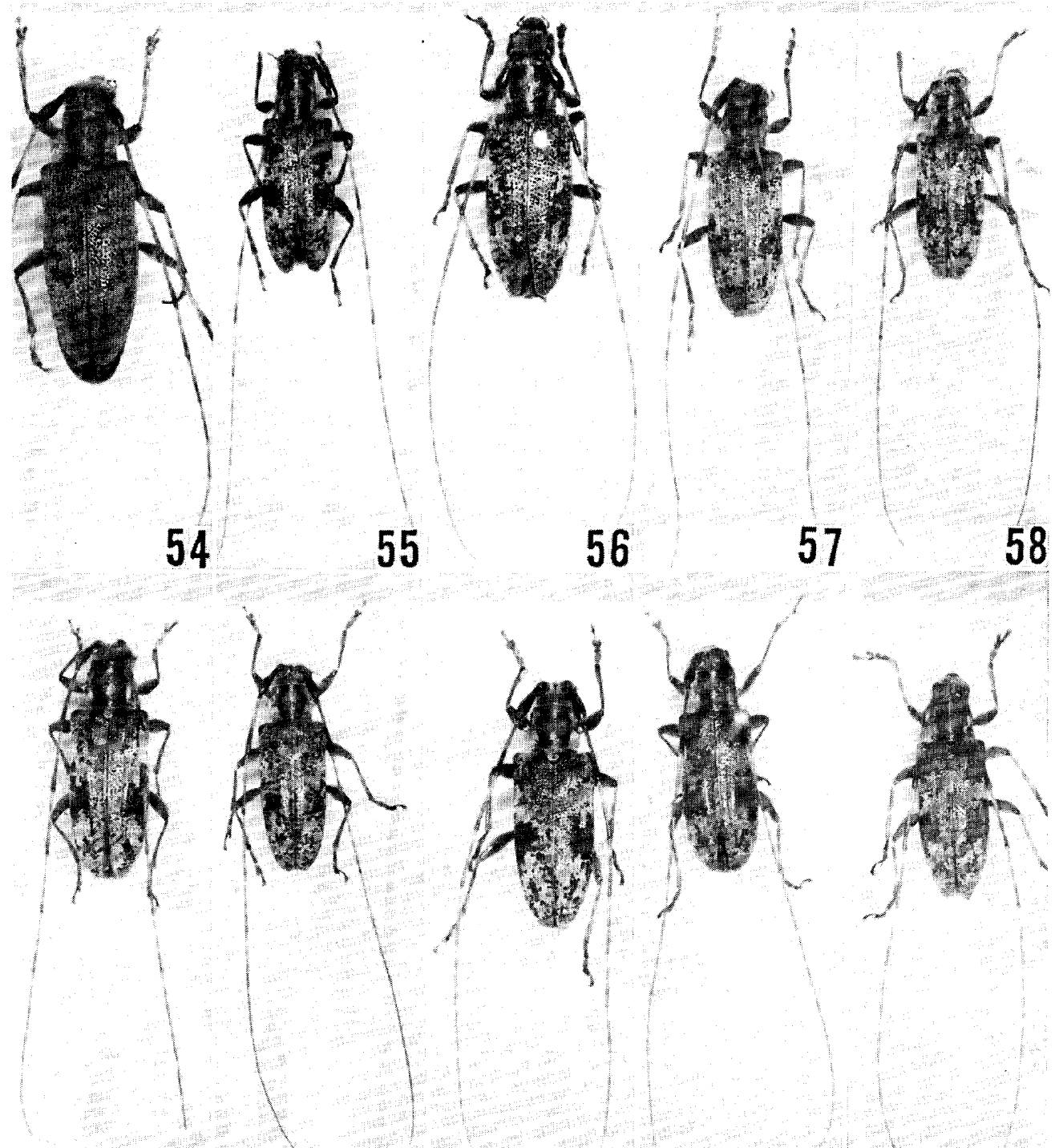

56

57

58
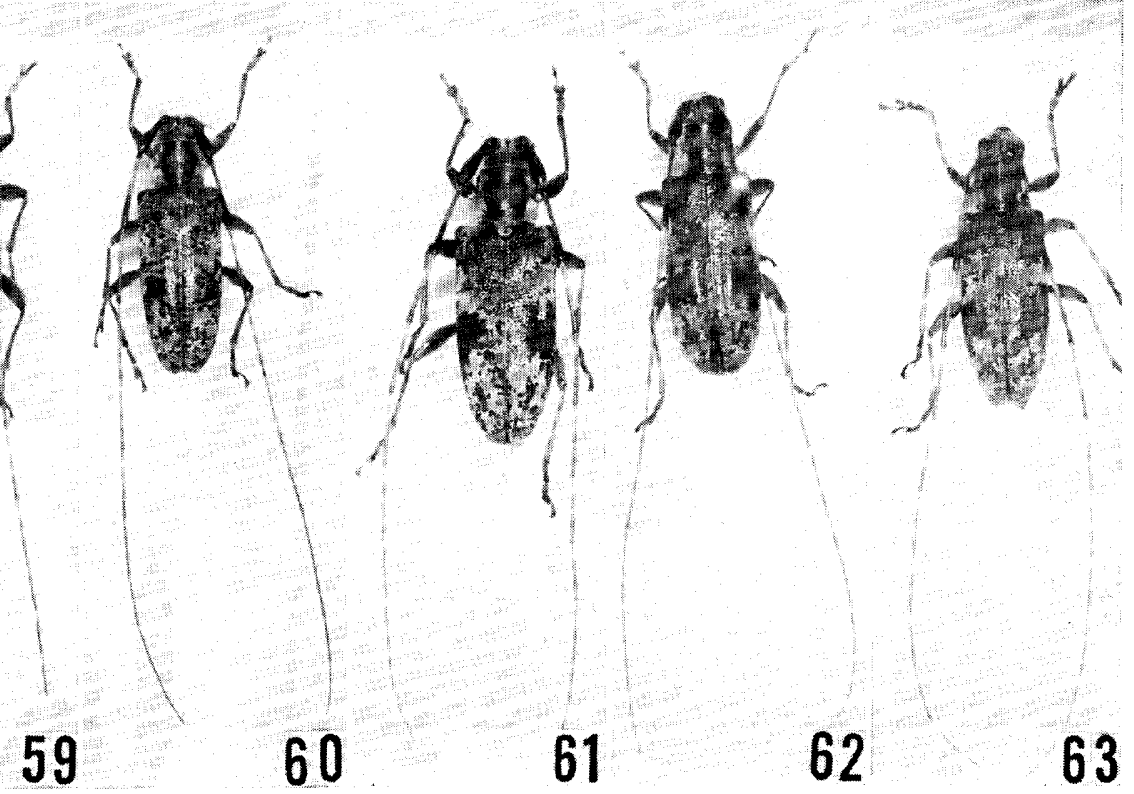

62

63

Figs. 54-63. Rhodopina spp. 54: meshimensis from Meshima I. 55: lewisii from Kyushu. 56: lewisii from Yakushima I. 57: orientalis from Kuchinoerabu I. 58: tokarensis obscura from Kuroshima 1. 59: tokarensis tokarensis from Nakanoshima I. 60: sp. from Amami-Ôshima I. 61: okinoerabuana from Okinoerabu I. 62: okinawana from Okinawa I. 63: sakishimana from Ishigaki I. (females). 
eye lobes $2 / 3$ times as long as gena; mouth parts with oblique golden yellow pubescence and hairs, sparsely with suberect short whitish yellow hairs on palpi; antennae short, relative length to body 1.76 , relative length of each segment 7.3: 1.7 : $13.3: 12.4: 11.2$ : 10.2: 9.7: 8.0: $7.7: 7.3: 11.2$; prostrate whitish yellow pubescence dense on segments 1-2, prostrate silver yellow pubescence dense on basal $3 / 4$ of segment 3 , basal $2 / 3$ of segments $4-6$, basal half of segment 7 , basal $1 / 3$ of segments $8-10$ and basal $4 / 5$ of segment 11 , suberect short sparse white hairs on segments l-11, a suberect long brown hair on segment 1 at near base, segment 4 at apical $1 / 3$, segments $5-6$ at apical $1 / 4$, segment 7 at basal half and segment 8 at basal $2 / 5$, prostrate brown pubescence dense on apical $1 / 4$ of segment 3 , apical $1 / 3$ of segments 4 6 , apical half of segment 7 , apical $2 / 3$ of segments $8-10$ and apical $1 / 5$ of segment 11, suberect long brown hairs on apices of segments 3-11 and suberect brown bristles sparsely on segment 2 at base.

Pronotum 0.86 times as long as broad, with a developed projection at each side, closely punctured at middle and roughly at apical and basal side, with three sulphureous yellow pubescent stripes, a narrow one in middle and two broad ones at sides, another part with prostrate greenish yellow pubescence, and erect long sparse brown hairs.

Scutellum semicircular, densely with prostrate golden yellow pubescence.

Elytra 2.18 times as long as broad ; humeri strongly developed and widest; disk deeply and strongly punctured on basal $1 / 3$ and shallowly and weakly on apical $2 / 3$, prostrate pubescence greenish yellow with several small irregular

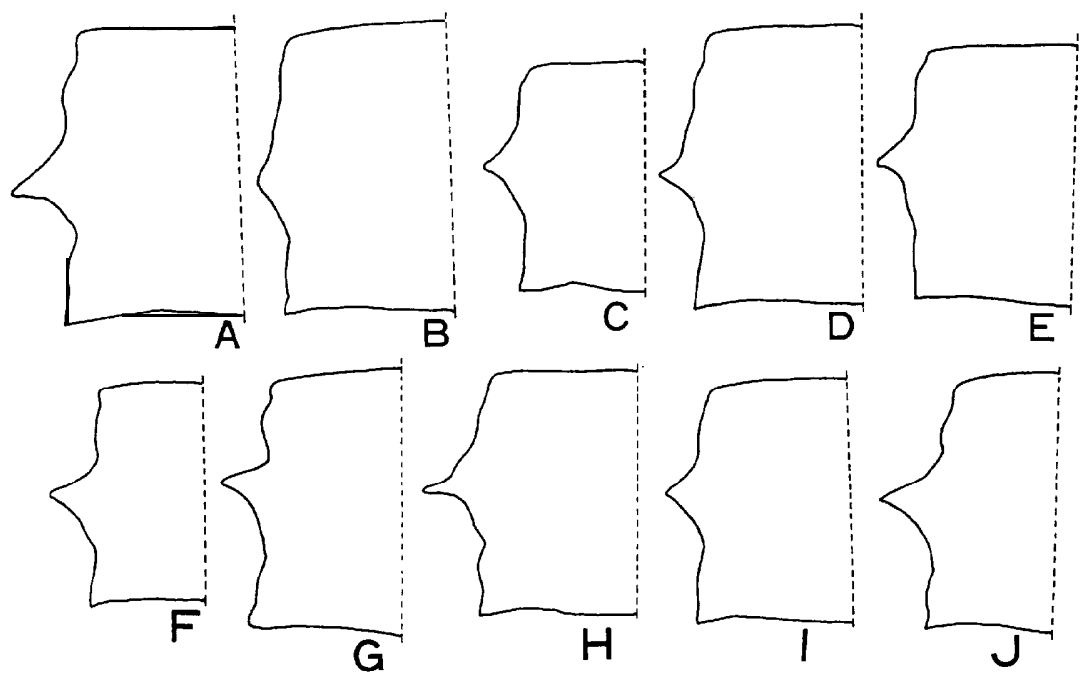

Fig. 64. Prothoracic projections of Rhodopina spp. A: meshimensis from MeshimaI. B: lewisii from Yakushima I. C: tokarensis obscura from Kuroshima I. D: orientalis from Kuchinoerabu I. E: tokarensis tokarensis from Nakanoshima I. F: okinoerabuana komiyai from Hachijo I. G : sp. from Amami-Ôshima I. H : okinoerabuana okinoerabuana from Okinoerabu I. I: okinawensis from Okinawa I. J: sakishimana from Ishigaki I. 
markings formed of prostrate blackish brown pubescence; apical part obtusely rounded

Ventral side not punctured, densely with prostrate greenish yellow pubescence; 7th abdominal sternite strongly concave at apical $1 / 3$.

Legs short, relative length of body to fore tibia 0.196; femora with dense, fair and prostrate greyish yellow pubescence; fore tibiae with dense, oblique brown setae at apices and on apical $1 / 4$ of ventral sides, another part with same pubescence as femora; mid and hind tibiae with same setae as fore tibiae at apices and on apical $1 / 3$ of dorsal and ventral sides, another part with dense, oblique golden yellow pubescence ; tarsi with sparse, oblique short brown hairs on claws, with dense prostrate greyish yellow pubescence on dorsal sides except for apical part of claws and dense, suberect silver yellow pubescence on ventral sides except for apical part of claws.

Length : $16.0 \mathrm{~mm}$, width : $5.7 \mathrm{~mm}$.

Distribution: Danjo Is. (Meshima I.).

Type material: Holotype 우 (Type No. 2206, Kyushu Univ.), Meshima I. of Danjo Is., 29. vi. 1978, M. Mogi leg.

Diagnosis: This new species is included in the Rhodopinalewisii group, but separable from congeneric species by the following key.

\section{KeY to SPECIES OF THE Rhodopina lewisii GROUP}

1. Lateral prothoracic projections developed (Fig. 64 A, C-J) …......................... 2

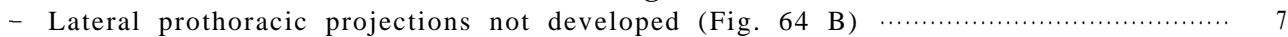

2. Lateral prothoracic projections well developed (Fig. 64 A, F, G, H, J) $\cdots \cdots \cdots \cdots \cdots \cdots \cdots \cdots$

- Lateral prothoracic projections not so well developed (Fig. 64 C-E, I) $\cdots \cdots \cdots \cdots \cdots \cdots \cdots \cdots$

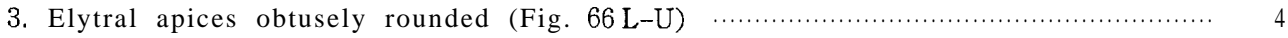

- Elytral apices acutely and obliquely truncate (Fig. 66 V), antennal scape moderately clavate (Fig. 66 K), elytral punctures very coarse at base, elytra with grey and chocolate brown pubescence, body length 12.8-15.6 mm

R. sakishimana Yokoyama

from Ishigaki I. and Iriomote I. of the Ryukyus (Figs. 63, 64 J, $65 \mathrm{~J}$ and 661)

4. Antennae long, more than 2.2 times as long as body, body without greenish yellow pubescence

- Antennae short, 1.76 times as long as body with greenish yellow pubescence, antennal scape wide and clavate (Fig. 66 A), elytra with small markings of blackish brown pubescence, elytral punctures rough at base, body length 16.0

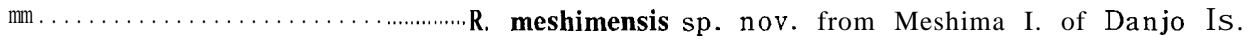

5. Elytra with small irregular dark chocolate brown or reddish brown pubescent

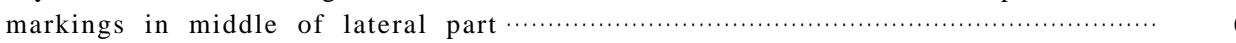

- Elytra with large irregular dark chocolate brown pubescent markings in middle of lateral part, antennal scape rather moderately clavate (Fig. 66 I), prothoracic punctures close, elytral punctures rough at base, elytral apices obtusely and slightly truncate (Fig. $66 \mathrm{~T}$ ), body length 12.3-15.2 $\mathrm{mm} \cdots \cdots \cdot$. R. okinoerabuana Hayashi from Okinoeabu I. of the Ryukyus (Figs. 61, 64H and $65 \mathrm{H}$ )

6. Elytral punctures very large and deep at base, elytra with rather rough yellowish brown pubescence, body length 11.0-12.6 $\mathrm{mm} \cdots$ R. okinoerabuana komiyai Hayas hi from Kôzu I., Miyake I., Mikura I. and Hachijo I. of Izu Is. (Figs. 64 F and 66 G, R) 

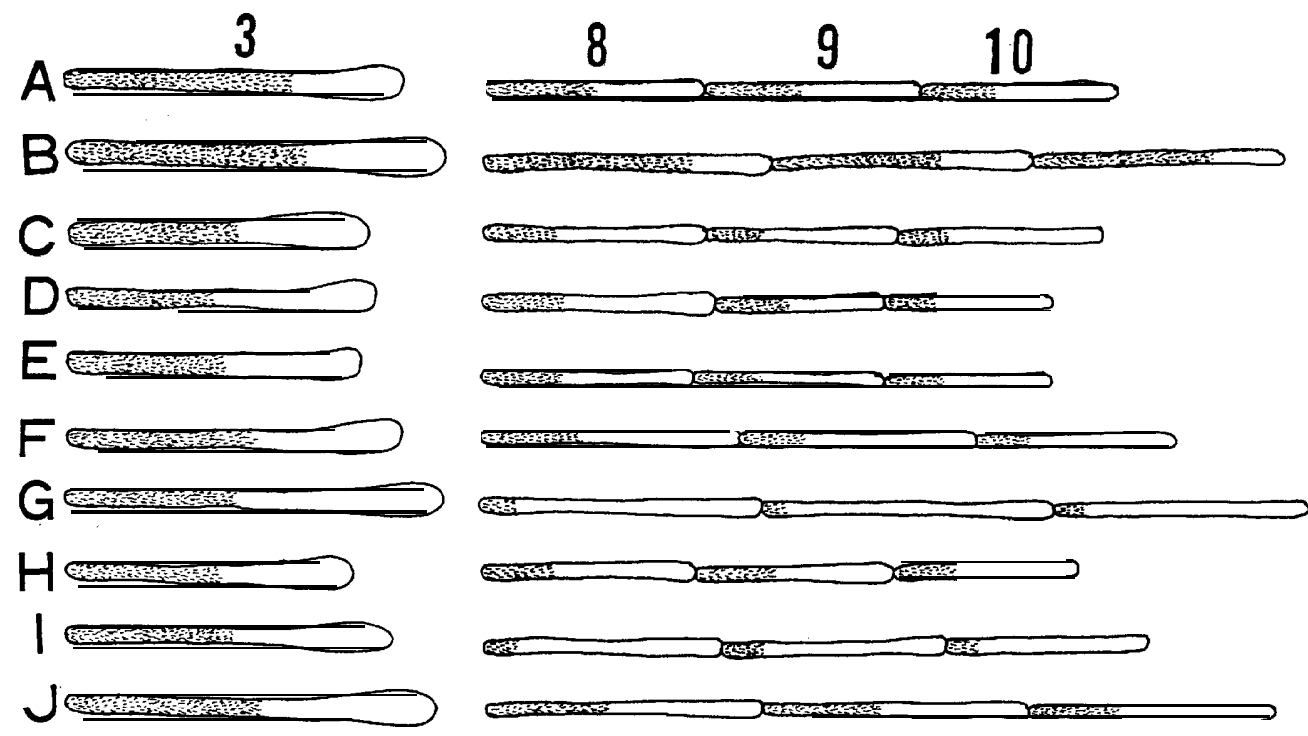

Fig. 65. Rhodopina spp. White pubescence of antennal segments 3 and 8-10. A: meshimensis from Meshima I. B: lewisii from Kyushu. C: Zewisii from Yakushima I. D: tokarensis $o b$ scura from Kuroshima I. E: orientalis from Kuchinoerabu I. F : tokarensis tokarensis from Nakanoshima I. G: sp. from Amami-Ôshima I. H: okinoerabuana from Okinoerabu I. I : okinawensis from Okinawa I. J: sakishimana from Ishigaki I.

- Elytral punctures somewhat small at base, elytra with grey or orange yellow pubescence, body length $12.5-15.2 \mathrm{~mm}$

from Amami-Ôshima I. and Tokunoshima I. of the Ryukyus (Figs. 60, 64 G, $65 \mathrm{G}$ and $66 \mathrm{H}, \mathrm{S}$ )

7. Body reddish brown, antennal segments $3-10$ each with whitish yellow pubescence on basal $1 / 3-1 / 2$, body length $10.5-16.5 \mathrm{~mm} \ldots \ldots \ldots \ldots \ldots \ldots \ldots$. lewisii (Bates)

from Yakushima I. and Tanegashima I. of Kagoshima Pref. (Figs. 56, 64 B, $65 \mathrm{C}$ and $66 \mathrm{C}, \mathrm{N}$ )

- Body blackish brown, antennal segments 3-10 with white pubescence on basal

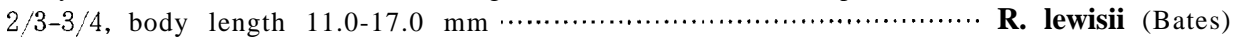

from Hokkaido, Honshu, Shikoku, Kyushu,

Sado I., Kanmuri I. and Koshiki Is. (Figs. 55, 64 B, 65B and 66 B, M)

8. Antennal segments $6-10$ with white pubescence on basal $2 / 5$, antennal segment 3 as long as 4, scape rather moderately clavate (Fig. 66 D-F) .......................... 9

- Antennal segments 6-10 with white pubescence on basal 1/5, antennal segment 3 shorter than 4, elytra closely punctured at base, elytral apices obtusely and obliquely truncate, scape strongly clavate, body length $12.5-15.0 \mathrm{~mm}$.............

R. okinawensis (Matsushita)

from Okinawa I. of the Ryukyus (Figs. 62, 64 I, 651 and 66 J, U)

9. Elytra with weakly depressed part on base

- Elytra with strongly depressed part on base, body length 14.0-17.0 mm...........

R. tokarensis tokarensis Hayashi

from Nakanoshima I. of Tokara Is. (Figs. 59, 64 E, 65 F and 66 F. Q)

10. Antennal segment 3 with white pubescence on basal half, body length $13.0 \mathrm{~mm}$

R. tokarensis obscura Makihara

from Kuroshima I. of Kagoshima Pref. (Figs. 58, 64 C, 65D and 66 D, 0) 


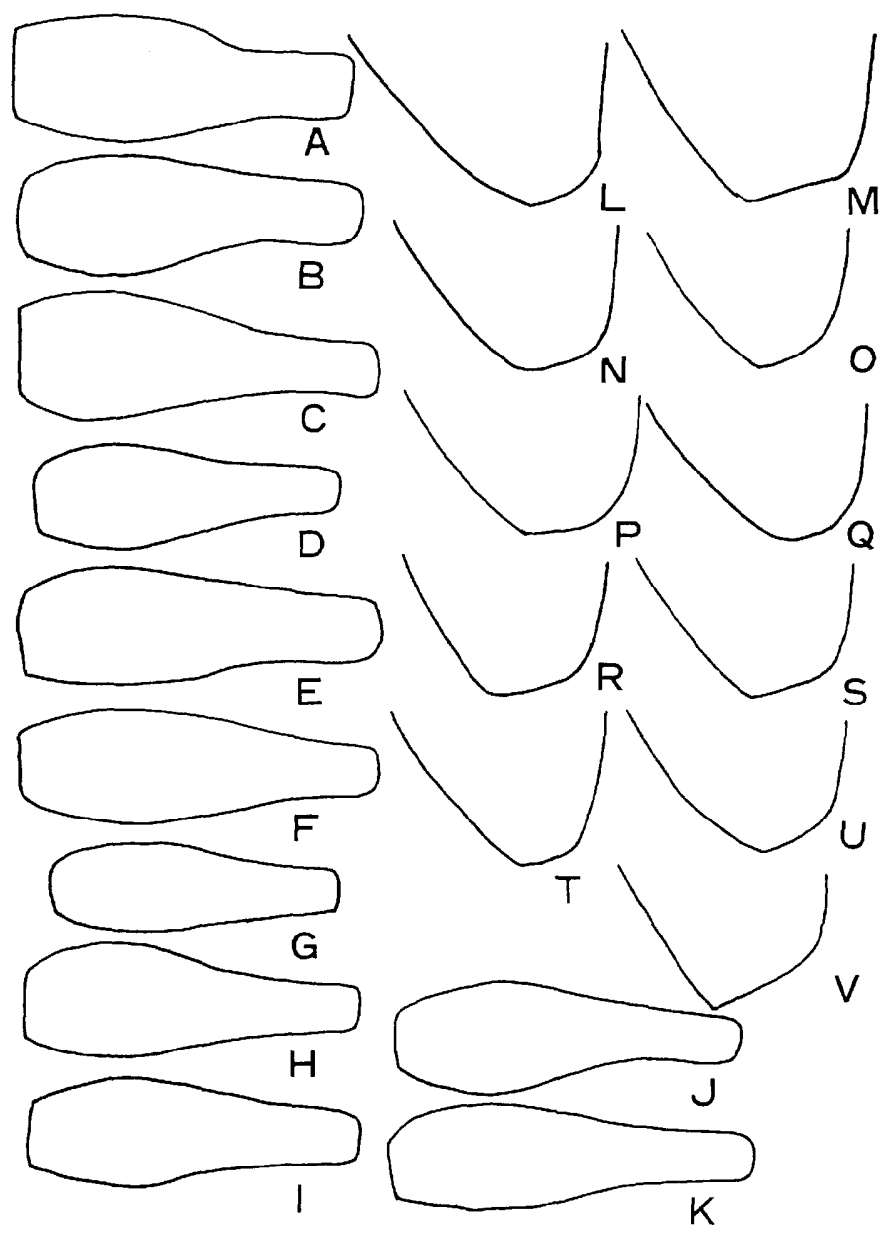

Fig. 66. Rhodopina spp. A-K: scapes and L-V: elytral apices. A and L: meshimensis from Meshima I. B and M: lewisii from Kyushu. $\mathrm{C}$ and $\mathrm{N}$ : lewisii from Yakushima $\mathrm{I}$. D and 0 : tokarensis obscura from Kuroshima I. E and P: orientalis from Kuchinoerabu I. F and Q: tokarensis tokarensis from Nakanoshima I. G: okinoerabuana komiyai from Mikura I. R: okinoerabuana komiyai from Hachijo I. H and S: sp. from Amami-Ôshima I. I and T: okinoerabuana okinoerabuana from Okinoerabu I. J and U: okinawensis from Okinawa I. K and V: sakishimana from Ishigaki I.

- Antennal segment 3 with white pubescence on basal 2/3, body length 12.3-16.0

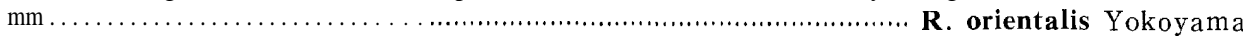
from Kuchinoerabu I. of Kagoshima Pref. (Figs. 57, 64 D, 65 E and 66 E, P)

\section{Mimectatina meridiana (Matsushita)}

(Fig. 68)

Doius meridianus Matsushita, 1933, Jour. Fac. Agr. Hokkaido Imp. Univ. 34: 380.

M imectatina meridiana : Hayashi, 1962, Ent. Rev. Japan 14(2): 38; Yamaguchi et al, 1973, Fauna and Flora Danjo Is.: 95. 


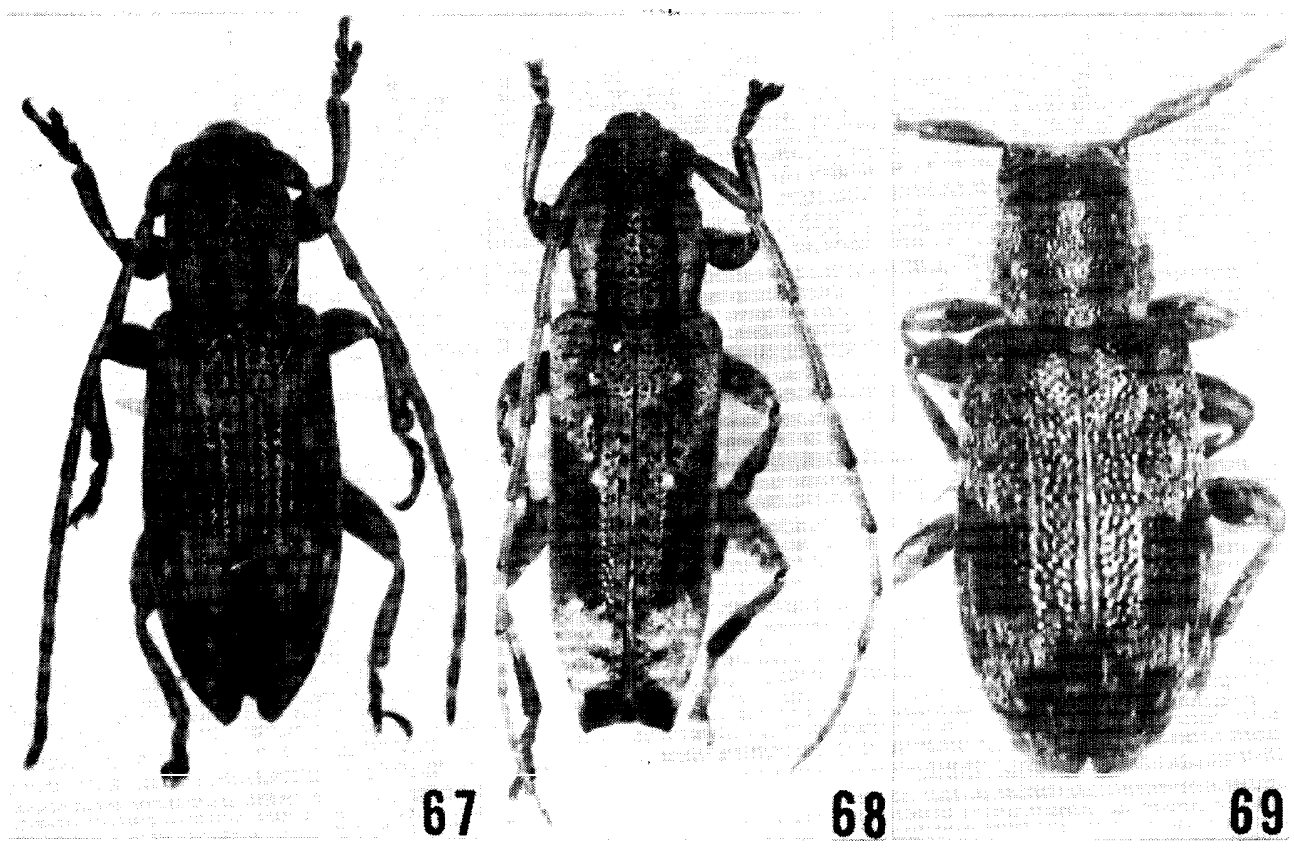

Figs. 67-69. 67: Sybra baculina nipponensis from Meshima I. 68: Mimectatina meridiana from Meshima I. 69: Miaenia tonsa from Meshima I.

SPecimens examined : Meshima I. : 1 ex. 7. vii. 1978, Y. Wada leg. ; 1 ex. 15. vii. 1978, Y. Wada leg.; 3 exs. 18. vii. 1978, Y. Wada leg.

D istribution: Shikoku, Kyushu, Izu-Ôshima I., Niijima I., Kôzu I., Miyake I., Mikura I., Hachijo I., Okinoshima I. (Kôchi Pref.), Okinoshima I. (Fukuoka Pref.), Danjo Is. (Oshima I. and Meshima I.), Koshiki Is., Tanegashima I., Yakushima I., Kuroshima I., Kuchinoshima I., Kuchinoshima I., Nakanoshima I., Takara I., Amami-Ôshima I., Tokunoshima I., Okinoerabu I., Okinawa I., Kumejima I., Miyake I., Irabu I., Tarama I., Ishigaki I., Iriomote I., Hateruma I. and Yonaguni I. ; Taiwan and Hawaii.

Tribe ACANTHOcININI

\section{Miaenia tonsa (Bates)}

(Fig. 69)

Exocentrus tonsus Bates, 1873, Ann. Mag. Nat. Hist. (4) 12: 385.

Miaenia tonsa: Hayashi, 1951, Ent. Rev. Japan 5(2): 82.

Sciades (Estoliops) tonsus: Breuning, 1977, Mitt. 2001. Mus. Berlin 53(2): 267.

Specimens examined: Meshima I. : 1 ex. 15. vii. 1978, Y. Wada leg. ; 1 ex. 18. vii. 1978, Y. Wada leg. Oshima I. : 1 ex. 7. viii. 1972, M. Noda leg.

Distribution: Honshu, Shikoku, Kyushu, Sado I., Izu-Ôshima I., Niijima I., Kôzu I., Miyake I., Mikura I., Hachijo I., Tsushima I., Danjo Is. (Meshima I. and Oshima I.), and Koshiki Is. 


\section{References}

Bates, H. W. 1873. On the Longicorn Coleoptera of Japan. Ann. Mag. Nat. Hist., (4) 12: 148-156, 193-201, 308-318, 380-390.

— 1884. Longicorn beetles of Japan. Jour. Linn. Soc. Zool., 18: 205-262.

Breuning, S. 1977. R\&vision de la tribu des Acanthocinini de la region Asiato-Australienne (Col., Cerambycidae) 2. Mitt. Zool. Mus. Berlin. 53(2): 199-274.

Gressitt, J. L. 1951. Longicorn beetles of China. Longicornia, 2: l-667, 22 pls.

Hayashi, M. 1951. Studies on Cerambycidae from Japan and its adjacent regions (1). Ent. Rev. Japan, 5(2): 75-82.

— 1961. Une nouvelle espèce de Rhodopina du nord des Iles Ryukyu (Col., Ceramb., Lamiinae). Bull. Osaka Mus. Nat. Hist., 13: 67-70.

— 1965. The Cerambycidae of Japan (Col.) (7). Ent. Rev. Japan, 18(1): 26-36. (In Japanese)

- 1969. Studies on Cerambycidae from Japan and its adjacent regions (Col.) (17). Ent. Rev. Japan, 21(2): 61-66.

- 1978. Studies on Asian Cerambycidae, 3 (Coleoptera). Ent. Rev. Japan, 32(1/2): 107111.

1979. The Cerambycidae of Japan (Col.) (11). Ent. Rev. Japan, 33(1/2): 109-119.

Komiya, J. \& K. Kusama. 1973. Two new species of the tribe Rhodopinini from Yakushima Island and Formosa (Coleoptera. Cerambycidae). Rep. Fac. Sci. Shizuoka Univ., 8: 137-140.

Kusama, K. 1973. The list of biology and distribution of Cerambycidae in Japan. New Insect Collecting. 3, Suppl.: 1-159. (In Japanese)

Makihara, H. 1977. Cerambycidae of Kuroshima Island, with descriptions two new species and two new subspecies (Coleoptera). Esakia, 10: 45-69.

Matsushita, M. 1933. Beitrag zur Kenntnis der Cerambyciden des japanischen Reichs. Jour. Fac. Agr. Hokkaido Imp. Univ., 34(2): 157-445, 5 pls.

Samuelson, G. A. 1965. The Cerambycidae of the Ryukyu Archipelago 2. Pacif. Ins., 7(2): 82-130.

Samuelson, G. A. \& J. L. Gressitt. 1965. The Cerambycidae of the Ryukyu Archipelago 1. Pacif. Ins., 7(1): 47-81.

Yamaguchi et al. 1973. Fauna and Flora of the Danjo Islands (Rep. Nagasaki Biol. Soc. Exped. Danjo Is.). Nagasaki, 1-224. (In Japanese)

Yokoyama, H. 1966. The Cerambycidae from Ryukyu and Satsunan Islands 1 (Coleoptera). Ent. Rev. Japan, $18(2)$ : 54-59.

1971. The Cerambycidae from Ryukyu and Satsunan Islands 2 (Coleoptera). Ent. Rev. Japan, 23(2): 93-101. 